\title{
U.S. DEPARTMENT ON THE INTERIOR
}

\section{U.S. GEOLOGICAL SURVEY}

Extraction of metals from raw clinoptilolite-rich rocks exposed to water in heavy-metal-polluted drainages

by

George A. Desborough ${ }^{1}$ and David Frishman ${ }^{1}$

Open-File Report 95-56

This report is preliminary and has not been reviewed for conformity with U.S. Geological Survey editorial standards or with the North American Stratigraphic Code. Any use of trade, product, or firm names is for descriptive purposes only and does not imply endorsement by the U.S. Government.

${ }^{1}$ Denver, Colorado 


\section{CONTENTS}

\section{Page}

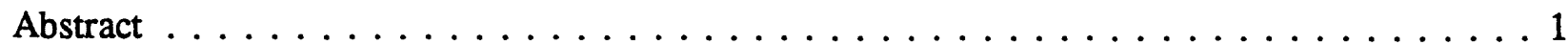

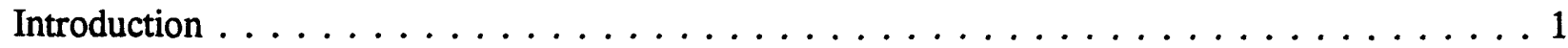

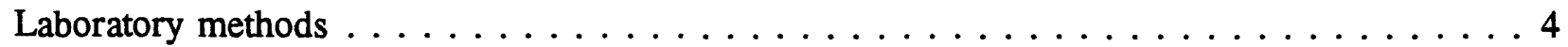

Results of preliminary exchange experiments $\ldots \ldots \ldots \ldots \ldots \ldots \ldots$

Secondary exchanges is near-saturated $\mathrm{NaCl}$ regenerant solutions $\ldots \ldots \ldots \ldots \ldots$

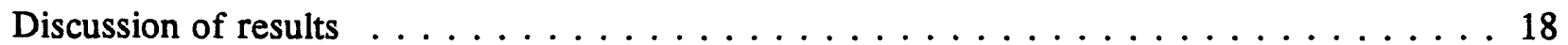

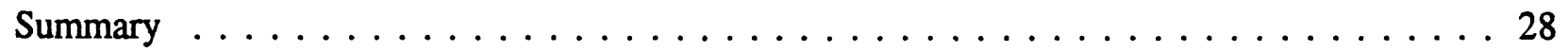

References cited $\ldots \ldots \ldots \ldots \ldots \ldots \ldots \ldots \ldots \ldots \ldots \ldots \ldots$

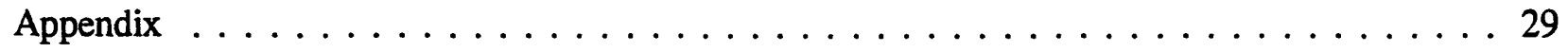

\section{ILLUSTRATIONS}

Figure 1. Heavy-metal-polluted drainages studied in Colorado in $1993 \ldots \ldots \ldots \ldots$

Figure 2. Concentrations of zinc in clinoptilolite-rich rocks (CRRs) before ammonium sulfate exchange versus the percentage of zinc remaining after the exchange. SD refers to South Dakota samples. Data are from table 2, and samples were initially exposed to California Gulch drainage water $\ldots \ldots \ldots \ldots \ldots \ldots$

Figure 3. Concentrations of lead in clinoptilolite-rich rocks (CRRs) before ammonium sulfate exchange versus the percentage remaining after the exchange. SD refers to South Dakota samples. Data from table 2, and the samples were initially exposed to California Gulch drainage water $\ldots \ldots \ldots \ldots \ldots \ldots$

Figure 4. Concentrations of zinc in clinoptilolite-rich rocks (CRRs) before sodium chloride exchanges versus the percentage remaining after the exchange. SD refers to South Dakota samples. Data from tables 2,3 , and $4 \ldots \ldots \ldots \ldots$

Figure 5. Concentrations of lead in clinoptilolite-rich rocks (CRRs) before sodium chloride exchange versus the percentage of lead remaining after the exchange. SD refers to South Dakota samples. Data from tables 2,3 , and $4 \ldots \ldots \ldots 13$

Figure 6. Relations of the mean $\mathrm{pH}$ of the heavy-metal-polluted drainage (HMPD) of metal capture versus the amount of copper remaining in clinoptilolite-rich rocks (CRRs) after 25 weight percent $\mathrm{NaCl}$ exchange. SD refers to South Dakota samples . . 19 
Figure 7. Relations of the mean $\mathrm{pH}$ of the heavy-metal-polluted drainage (HMPD) of metal capture versus the amount of zinc remaining in clinoptilolite-rich rocks (CRRs) after 25 weight percent $\mathrm{NaCl}$ exchange. SD refers to South Dakota samples . . 20

Figure 8. Relations of the mean $\mathrm{pH}$ of the heavy-metal-polluted drainage (HMPD) of metal capture versus the amount of lead remaining in clinoptilolite-rich rocks (CRRs) after 25 weight percent $\mathrm{NaCl}$ exchange. SD refers to South Dakota samples . . . 21

Figure 9. Relations of the mean $\mathrm{pH}$ of the heavy-metal-polluted drainage (HMPD) of metal capture versus the amounts of copper + zinc + lead remaining in the clinoptiloliterich rocks (CRRs) after 25 weight percent $\mathrm{NaCl}$ exchange. SD refers to South Dakota samples . . . . . . . . . . . . . . . . . 22

Figure 10. Relations of the mean $\mathrm{pH}$ of HMPD water and the influence on the final $\mathrm{pH}$ of the 25 percent $\mathrm{NaCl}$ exchange solution. SD refers to South Dakota clinoptilolite-rich

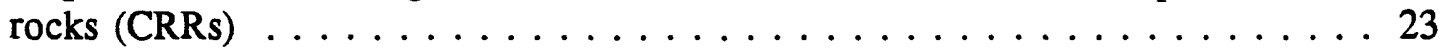

Figure 11. Relations of the percent of $\mathrm{Zn}$ remaining in clinoptilolite-rich rocks (CRRs) after 25 percent $\mathrm{NaCl}$ exchange to the final $\mathrm{pH}$ of the 25 percent $\mathrm{NaCl}$ exchange solution . . . . . . . . . . . . . . . . . . . . . 25

Figure 12. Relations of the percent of $\mathrm{Pb}$ remaining in clinoptilolite-rich rocks (CRRs) after 25 percent $\mathrm{NaCl}$ exchange to the final $\mathrm{pH}$ of the 25 percent $\mathrm{NaCl}$ exchange

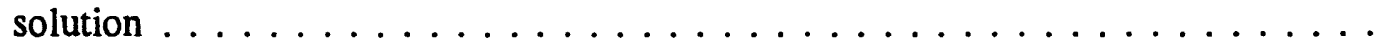

Figure 13. Relations of the percent of $\mathrm{Cu}+\mathrm{Zn}+\mathrm{Pb}$ remaining in clinoptilolite-rich rocks (CRRs) after 25 percent $\mathrm{NaCl}$ exchange to the final $\mathrm{pH}$ of the 25 percent $\mathrm{NaCl}$ exchange solution . . . . . . . . . . . . . . . . . 27

\section{TABLES}

Table 1. Raw clinoptilolite-rich rock (CRR) samples tested for heavy-metal capture in heavymetal-polluted drainage water in Colorado in 1993 (Desborough, 1994) . . . . . 3

Table 2. Heavy metals captured and heavy metals remaining (final) in clinoptilolite-rich rocks (CRRs) after laboratory cation-exchange tests using common cations and acids . . 7

Table 3. Heavy metals captured and heavy metals remaining (final) in clinoptilolite-rich rocks (CRRs) after laboratory cation-exchange tests using $\mathrm{NaCl}$ and dilute $\mathrm{HCl} \ldots \ldots 9$

Table 4. Heavy metals captured and heavy metals remaining (final) in clinoptilolite-rich rocks (CRRs) after laboratory cation-exchange tests using $\left(\mathrm{NH}_{4}\right)_{2} \mathrm{SO}_{4}, \mathrm{NaCl}$, and

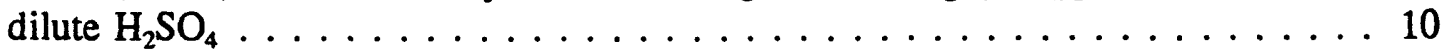


Table 5. Heavy metals captured and heavy metals remaining (final) in clinoptilolite-rich rocks (CRRs) after laboratory cation-exchange tests using $\mathrm{NaCl}$ and acidified- $\mathrm{NaCl}$

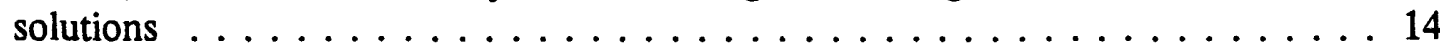

Table 6. Results of 25 weight percent $\mathrm{NaCl}$ exchanges for the three best performing clinoptilolite-rich rocks (CRRs) for heavy-metal capture in the Argo tunnel drain, Idaho Springs, Colorado . . . . . . . . . . . . . . . 15

Table 7. Results of 25 weight percent $\mathrm{NaCl}$ exchanges for the three best performing clinoptilolite-rich rocks (CRRs) for heavy-metal capture for three tests in lower California Gulch and one test in upper California Gulch . . . . . . . . 16

Table 8. Results of 25 weight percent $\mathrm{NaCl}$ exchanges for the three best performing clinoptilolite-rich rocks (CRRs) for heavy-metal capture in upper Mineral Creek and the Rawley tunnel at Bonanza . . . . . . . . . . . . . . . 17

Table 9. Results of 25 weight percent $\mathrm{NaCl}$ exchanges for the three best performing clinoptilolite-rich rocks (CRRs) for heavy-metal capture in the Wellington mine

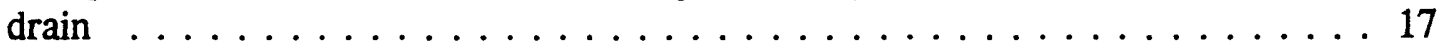

Table 10. Lead captured from polluted drainage water by FLW and SDA clinoptilolite-rich rocks (CRRs) and lead lost in 17 exchanges in ammonium sulfate and sodium

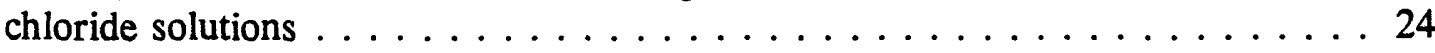




\section{ABSTRACT}

Clinoptilolite-rich rocks (CRRs) that were exposed to water in five heavy-metal-polluted drainages (HMPDs) in Colorado in 1993 were studied in the laboratory to determine the exchangeability of the captured metals. CRRs were treated with aqueous solutions of 0.25 to 10 weight percent ammonium sulfate, 10 to 25 weight percent sodium chloride, and dilute acetic, sulfuric, and hydrochloric acid. Weight ratios of CRR to aqueous exchange solutions varied from $1: 1$ to $1: 10$.

The most significant result of this study is that the exchangeability of $\mathrm{Cu}, \mathrm{Zn}$, and $\mathrm{Pb}$ in near-neutral, 25 weight percent $\mathrm{NaCl}$ solutions appears to be a function of the $\mathrm{pH}$ of the water in the HMPD from which these metals were captured. This is because $\mathrm{H}^{+}$is also captured by the CRRs in low pH waters in some drainages, and is displaced by $\mathrm{Na}$ in the exchange solution. The $\mathrm{pH}$ of the $\mathrm{NaCl}$ exchange solution decreases and the amount of $\mathrm{Cu}, \mathrm{Zn}$, and $\mathrm{Pb}$ released by CRRs increases. Conversely, when these metals are captured from drainages of higher $\mathrm{pH}$, the $\mathrm{pH}$ of the $\mathrm{NaCl}$ exchange solution is depressed only slightly by $\mathrm{H}^{+}$release from CRRs and thus the amount of metals released by CRRs is smaller.

This difference in metal exchangeability in 25 percent $\mathrm{NaCl}$ solutions ranges over several orders of magnitude for $\mathrm{Cu}$ and $\mathrm{Zn}$. These results indicate that there would be little chance of efficiently recycling $\mathrm{CRRs}$ using near-neutral $\mathrm{NaCl}$ exchange solutions after heavy-metal capture from streams with $\mathrm{pH}$ above about 5.5.

Of the 14 CRRs tested, the Ft. LaClede, Wyo., CRR is the most efficient for $\mathrm{Cu}$ and $\mathrm{Zn}$ capture in HMPDs where the water has a $\mathrm{pH}$ of 3 to 4 . This CRR also released the most $\mathrm{Cu}$ and $\mathrm{Zn}$ during treatment with $\mathrm{NaCl}$ solutions.

For most of the cation-exchange tests, the South Dakota CRR consistently retained more $\mathrm{Cu}, \mathrm{Zn}$, and $\mathrm{Pb}$ than the other CRRs, regardless of the $\mathrm{pH}$ of the HMPD from which these metals were captured. For the 25 percent $\mathrm{NaCl}$ exchanges, the South Dakota CRR retained 55 to 95 percent of the captured $\mathrm{Cu}+\mathrm{Zn}+\mathrm{Pb}$ for 14 of 15 tests. The other CRRs retained only 8 to 75 percent of the captured $\mathrm{Cu}+\mathrm{Zn}+\mathrm{Pb}$ in 20 tests of the 25 percent $\mathrm{NaCl}$ treatment.

The efficient capture of $\mathrm{Pb}$ from water and the retention of that $\mathrm{Pb}$ after exposure of the $\mathrm{CRR}$ to ammonium sulfate-rich or $\mathrm{NaCl}$-rich cation-exchange solutions may be useful for immobilizing $\mathrm{Pb}$ in soils or mine tailings that contain soluble $\mathrm{Pb}$.

The differences in metal release reported here should make it possible to use CRRs in several different ways to remediate polluted sites. However, because even a single type of CRR responds differently concerning metal uptake and metal release under different conditions, site specific testing is imperative before use of CRR is attempted.

\section{INTRODUCTION}

Preliminary cation-exchange tests were done in the laboratory to examine removal of $\mathrm{Cu}$, $\mathrm{Zn}$, and $\mathrm{Pb}$ from clinoptilolite-rich rocks (CRRs) that had captured these metals from water in five heavy-metal-polluted drainages (HMPDs) during field tests in Colorado in 1993 (Desborough, 1994). These sites are shown on figure 1.

Schultz and Zamzow (1993) were very successful using CRR to capture heavy metals from very acidic mine water $(\mathrm{pH}=2.2$ ) and then regenerating the CRR (removing the metals from it) with 20 weight percent $\mathrm{NaCl}$ solutions. Similarly, Vos and O'Hearn (1993) successfully used the zeolite group mineral phillipsite to capture heavy metals from acidic mine wastewater $(\mathrm{pH}=3.6)$ and subsequently regenerated the phillipsite with both synthetic three weight percent 


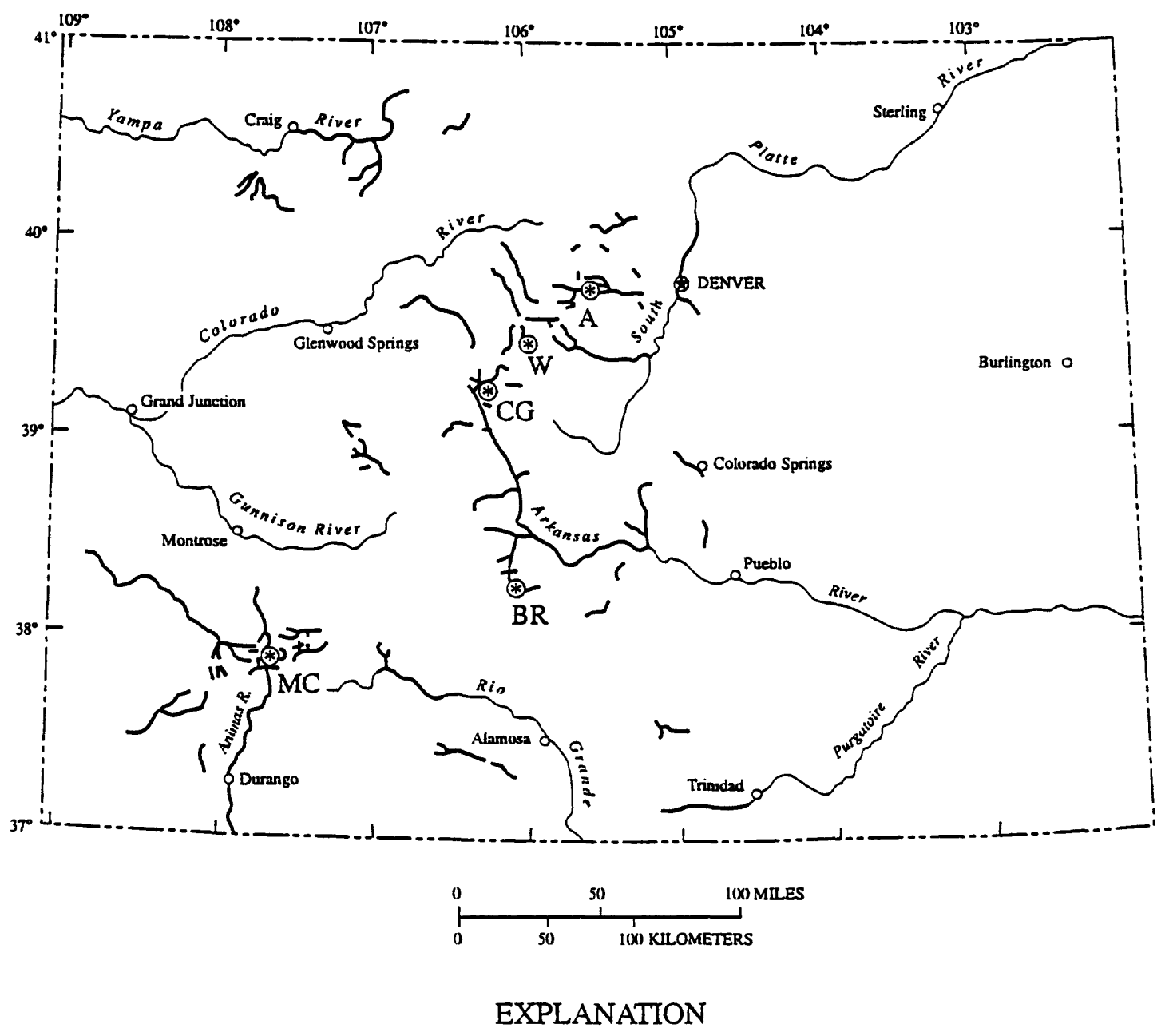

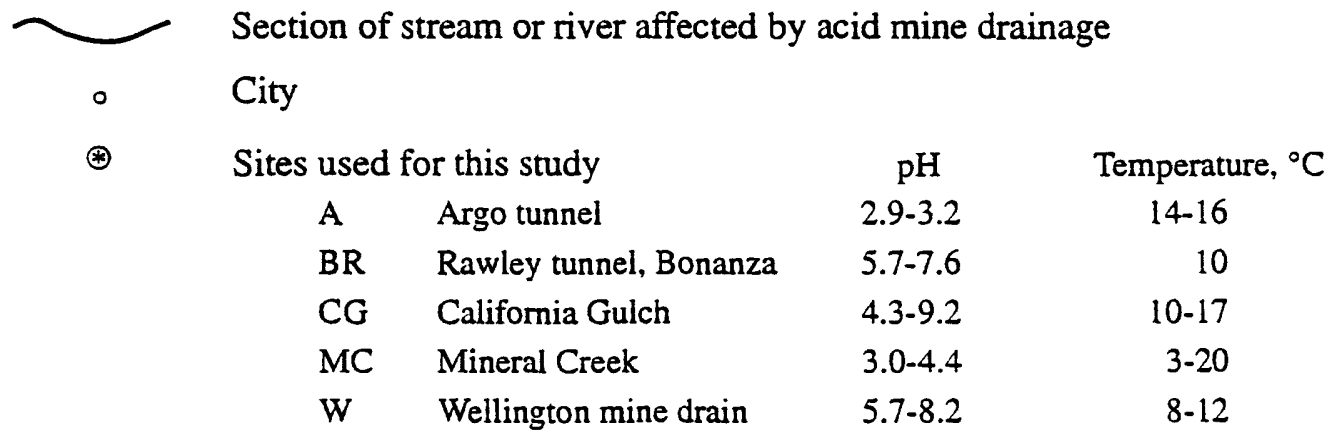

Figure 1. Heavy-metal-polluted drainages studied in Colorado in 1993. 
$\mathrm{NaCl}$ solutions and sea water. We are not aware of other studies concerning the removal of heavy metals from natural zeolite that captured heavy metals from waste streams or natural drainages of $\mathrm{pH}>4$.

Some of these heavy-metal-removal tests were designed to examine the relative permanence of heavy-metal sequestration by CRRs; this was done to evaluate passive use of CRRs in HMPDs and other environments with soluble heavy metals such as soils, mine tailings, municipal waste disposal areas, and hazardous waste disposal sites. Heavy-metal sequestration in some CRRs may isolate and immobilize heavy metals enough to meet the "Toxicity Characteristic Leaching Procedure" (TCLP) standards of the Environmental Protection Agency (1990, EPA Method 1311). If so, this could reduce disposal costs for some otherwise "hazardous waste."

In 99 preliminary laboratory experiments, solutions of ammonium sulfate, sodium chloride, and dilute acetic, sulfuric, and hydrochloric acid were used; a range of CRR:exchange solution ratios and different experimental durations were also used. The last set of 36 separate exchange tests was done using 25 weight percent $\mathrm{NaCl}$ solutions in a CRR:solution ratio of 1:3. Cation-exchange tests using ammonium $\left(\mathrm{NH}_{4}{ }^{+}\right)$were done to evaluate heavy-metal mobility, or solubility, under conditions where highly soluble synthetic fertilizers are used in agricultural environments.

Table 1 lists the localities and abbreviations used for the CRR samples studied here. Chemical and mineralogical data for these are given in the Appendix.

Table 1.-Raw clinoptilolite-rich rock (CRR) samples tested for heavy-metal capture in heavy-metal-polluted drainage water in Colorado in 1993 (Desborough, 1994)

[This list shows the abbreviations used here for each CRR and the CRR deposit location. Only CRRs mentioned in this report are listed here]

\begin{tabular}{|c|c|}
\hline Locality and abbreviation & Locality and abbreviation \\
\hline British Columbia & South Dakota (3 samples from one deposit) \\
\hline Princeton-PBC & SD1 \\
\hline Colorado & SDA \\
\hline Creede-CCO & SDC \\
\hline Idaho & Texas \\
\hline Crisman Hill-CHI & Alamito Creek-ACT \\
\hline Nevada & Tilden-TT \\
\hline Fish Creek Mountains-FCEN (east pit) & Wyoming \\
\hline Fish Creek Mountains-FCWN (west pit) & Ft. LaClede-FLW \\
\hline \multicolumn{2}{|l|}{ Oregon } \\
\hline \multicolumn{2}{|l|}{ Harney Lake-HLO } \\
\hline Sheaville-SVO & \\
\hline
\end{tabular}




\section{LABORATORY METHODS}

Samples of sized clinoptilolite-rich rocks (CRRs) that were exposed to water in five heavy-metal-polluted drainages (HMPDs) in 1993 (Desborough, 1994) were used for this cationexchange study. These CRR samples $(2.0 \times 4.7 \mathrm{~mm})$ had been analyzed previously for heavy metals and were powdered ( 95 percent $<0.15 \mathrm{~mm}$ ) to make them suitable for nondestructive energy-dispersive X-ray analysis. These samples were exposed to different exchange solutions in the laboratory at several CRR:solution weight ratios for fixed periods of time. Samples were at rest during exposure to exchange solutions. All cation-exchange tests in the laboratory used reagent-grade cation salts and reagent-grade acids; tap water was used to make all solutions. After exposure to each exchange solution, samples were washed with water to remove soluble salts, retained on filter paper, dried at $50^{\circ} \mathrm{C}$, and then analyzed to determine their heavy-metal content after the exchange. The precision of the measurements for $\mathrm{Cu}$ and $\mathrm{Zn}$ is better than 10 percent, relative; for $\mathrm{Pb}$ precision is about 10 percent, relative. Results are reported to three significant figures because each is the mean of three separate analyses. A series of 99 preliminary experiments was conducted for use as a guide in subsequent cation-exchange studies. Tables 2 through 5 tabulate the results of these experiments. These tables are organized by drainage basin, one table each for the four HMPDs in which CRRs were placed to capture metals from the water. Results from experiments on CRRs immersed in the fifth drainage, the Argo tunnel, will be presented separately.

\section{RESULTS OF PRELIMINARY EXCHANGE EXPERIMENTS}

The ammonium sulfate exchanges were done to examine heavy-metal mobility at relatively high and low ammonium concentrations. The lowest concentration of ammonium sulfate used ( 0.25 weight percent) approximates maximum agricultural applications of synthetic fertilizer for high-value crops such as potatoes or corn (Kenneth Barberick, Colorado State University, oral commun., 1993). All CRRs show some $\mathrm{Zn}$ and minor $\mathrm{Pb}$ exchange for the high concentrations of ammonium sulfate; however, at lower concentrations of 0.25 and 0.5 weight percent of ammonium sulfate, the South Dakota (SD) CRRs retain nearly all of the captured $\mathrm{Pb}$ and most of the $\mathrm{Zn}$. Figure 2 shows the percentages of captured $\mathrm{Zn}$ remaining in the CRRs after exposure to the ammonium sulfate solutions listed in table 2. The South Dakota samples retained 87 to 100 percent of the captured $\mathrm{Zn}$. Figure 3 shows the percentages of captured $\mathrm{Pb}$ remaining in the CRRs after exposure to the ammonium sulfate solutions listed in table 2; all samples retained 88 to 100 percent of the $\mathrm{Pb}$. Therefore, some CRRs may be of use for soil amendment in agricultural applications after heavy-metal capture. The South Dakota CRRs seem to sequester the $\mathrm{Pb}$ at low concentrations of ammonium sulfate even where CRR:exchange solution ratios are 1:10. Because of the large amounts of exchangeable Na in the FLW CRR, it would be inadvisable to use it for agronomic purposes without major chemical pretreatment for removal of exchangeable $\mathrm{Na}$. Sodium is toxic to most plants.

For the 20 and 25 weight percent $\mathrm{NaCl}$ exchanges, the FLW and TT CRRs lost much more $\mathrm{Zn}$ and $\mathrm{Pb}$ to the Na-rich solution than did the three SD CRRs that released no $\mathrm{Cu}$ or $\mathrm{Pb}$ during the 47-hour exchange (table 2). As will be shown later, this apparent discrepancy is due to the different $\mathrm{pH}$ 's of the water in the HMPD from which the CRRs originally collected the $\mathrm{Cu}, \mathrm{Zn}$, and $\mathrm{Pb}$. The samples exchanged with the 20 weight percent $\mathrm{NaCl}$ solution collected their metals from water with a mean $\mathrm{pH}$ of 4.6 , whereas the 25 weight percent $\mathrm{NaCl}$ exchange 


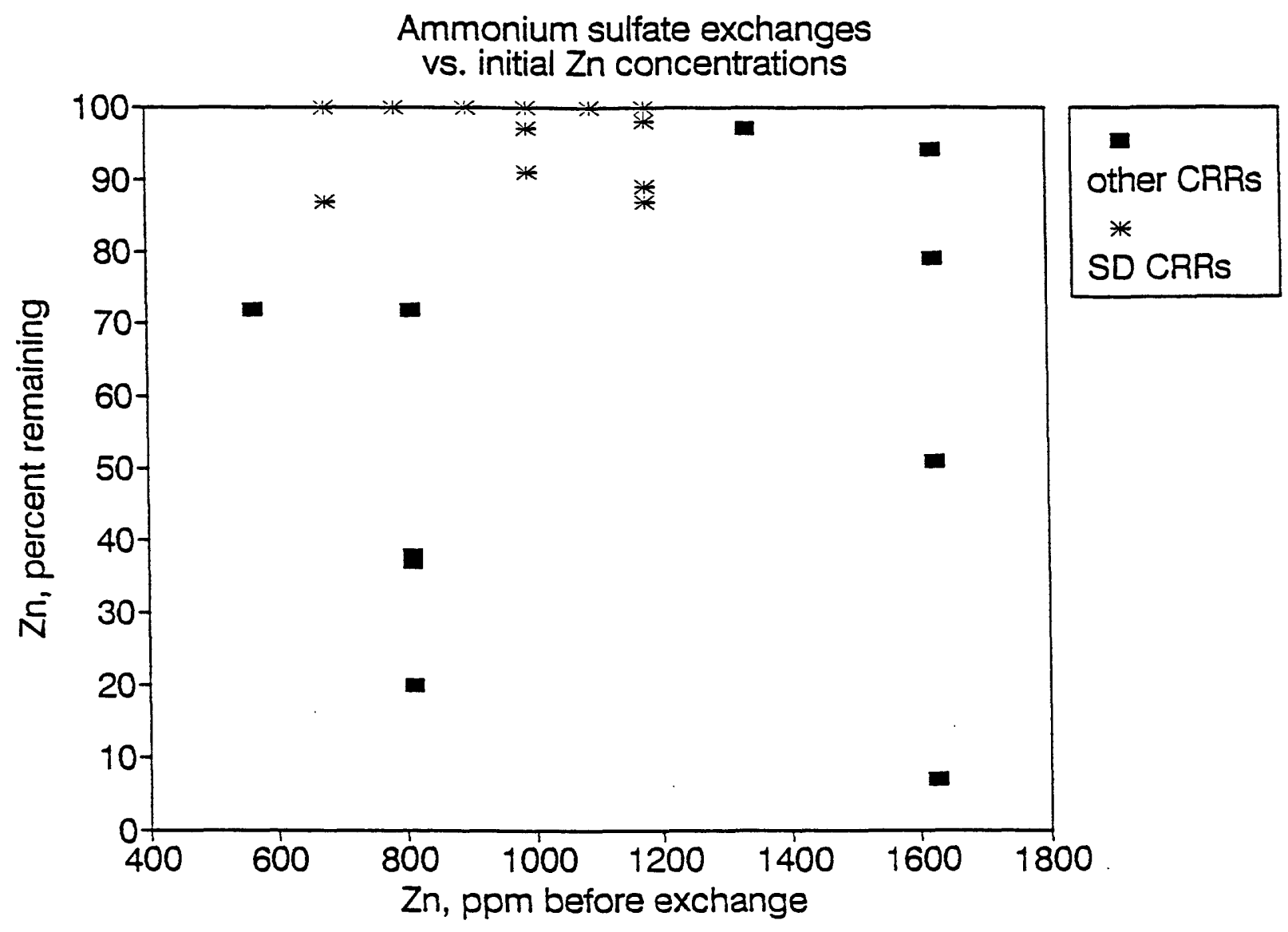

Figure 2.-Concentrations of zinc in clinoptilolite-rich rocks (CRRs) before ammonium sulfate exchange versus the percentage of zinc remaining after the exchange. SD refers to South Dakota samples. Data are from table 2, and samples were initially exposed to California Gulch drainage water. 


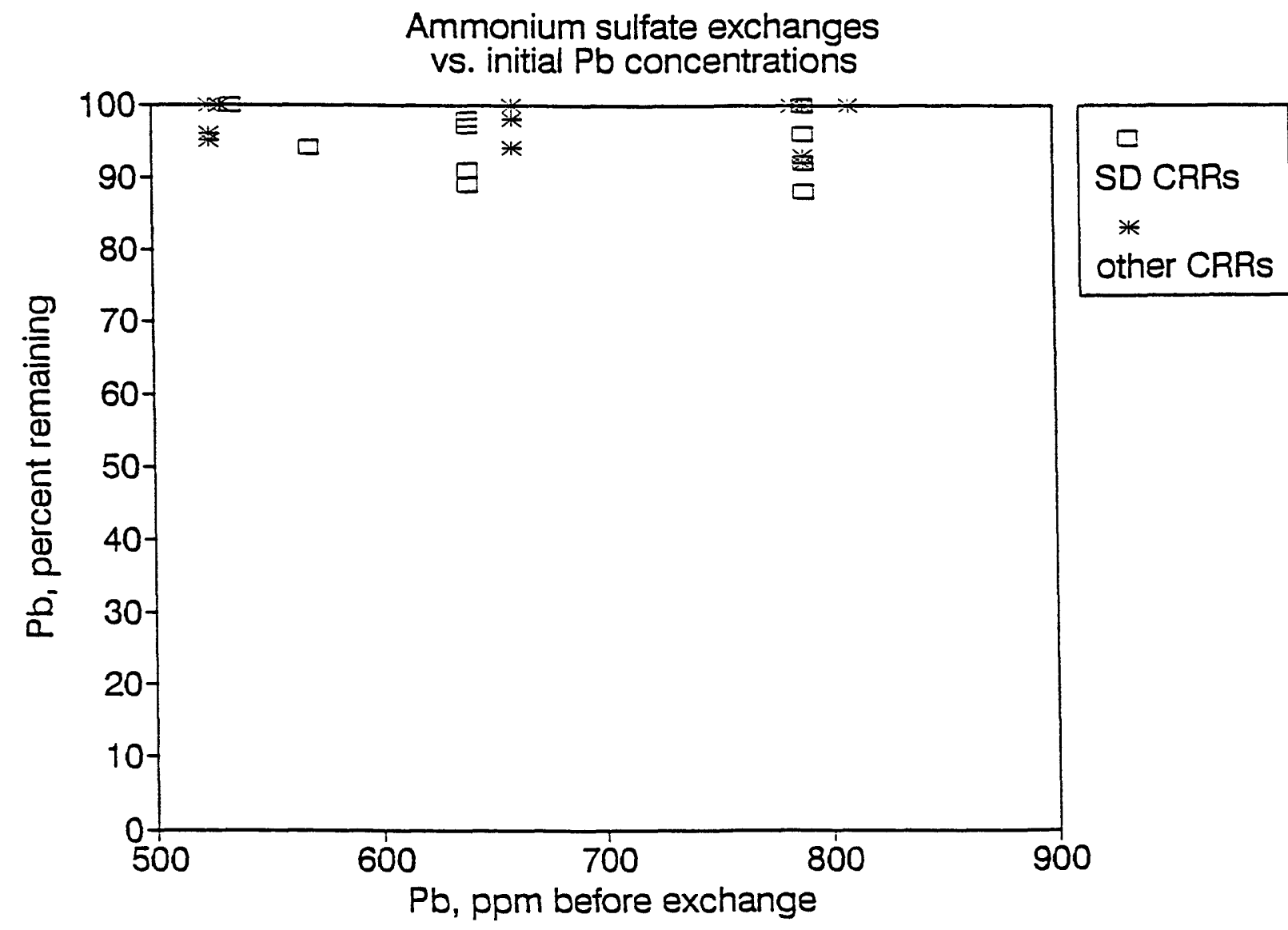

Figure 3.-Concentrations of lead in clinoptilolite-rich rocks (CRRs) before ammonium sulfate exchange versus the percentage remaining after the exchange. SD refers to South Dakota samples. Data from table 2, and the samples were initially exposed to California Gulch drainage water. 
experiments were performed with samples of CRR that collected their metals from water with a $\mathrm{pH}$ of 5.5 .

In the 119-hour experiments, using the 0.25 weight percent ammonium sulfate solution, no significant amounts of $\mathrm{Cu}, \mathrm{Zn}$, and $\mathrm{Pb}$ were lost to the solutions (table 2).

The last exchange experiment listed in table 2 was designed to simulate the Toxic Contaminant Leach Procedure (TCLP) defined by the U.S. Environmental Protection Agency (U.S. EPA, 1990). In this exchange in glacial acetic acid for 118 hours, no $\mathrm{Pb}$ was leached from the CRRs.

Table 2.-Heavy metals captured and heavy metals remaining (final) in clinoptilolite-rich rocks

(CRRs) after laboratory cation-exchange tests using common cations and acids

[CRR was powdered to minus 100 mesh $(<0.15 \mathrm{~mm})$. i.s. = insufficient sample]

\begin{tabular}{cccccc}
\hline CRR & $\begin{array}{c}\text { CRR:Exchange } \\
\text { Solution }\end{array}$ & initial $^{\mathrm{Cu}}$ (final) & initial & $\mathrm{Zn}$, (final) $_{\text {initial }}^{\text {Pb, }}$ (final) \\
\hline
\end{tabular}

lower California Gulch (5/29/93-6/4/93)

Ammonium exchanges

$3 \mathrm{~g} \mathrm{CRR}$ in $3 \mathrm{ml}$ of $10 \mathrm{wt}$. \% $\left(\mathrm{NH}_{4}\right)_{2} \mathrm{SO}_{4} ; 25.7 \mathrm{~h}$.

\begin{tabular}{|c|c|c|c|c|c|c|c|}
\hline FLW & 1:1 & 10 & $(0)$ & 1,625 & $(830)$ & 640 & (620) \\
\hline SD1 & & 30 & (0) & 680 & $(590)$ & 790 & (725) \\
\hline SDA & & 55 & (0) & 1,180 & $(1,060)$ & 525 & (500) \\
\hline SDC & & 50 & $(50)$ & 995 & (905) & 660 & (620) \\
\hline $\mathrm{TT}$ & & 50 & (0) & 810 & (300) & 790 & (725) \\
\hline
\end{tabular}

$3 \mathrm{~g} \mathrm{CRR}$ in $9 \mathrm{ml}$ of 10 wt. $\%\left(\mathrm{NH}_{4}\right)_{2} \mathrm{SO}_{4} ; 24.0 \mathrm{~h}$.

\begin{tabular}{|c|c|c|c|c|c|c|c|}
\hline FLW & $1: 3$ & 10 & (10) & 1,625 & (115) & 640 & (570) \\
\hline SD1 & & 30 & (15) & 680 & $(680)$ & 790 & (735) \\
\hline SDA & & 55 & (55) & 1,180 & $(1,050)$ & 525 & (505) \\
\hline SDC & & 50 & (0) & 995 & (995) & 660 & (645) \\
\hline TT & & 50 & (10) & 810 & (160) & 790 & (695) \\
\hline
\end{tabular}

$2.5 \mathrm{~g} \mathrm{CRR}$ in $25 \mathrm{ml}$ of 0.5 wt. \% $\left(\mathrm{NH}_{4}\right)_{2} \mathrm{SO}_{4} ; 68 \mathrm{~h}$.

\begin{tabular}{|c|c|c|c|c|c|c|c|}
\hline FLW & 1:10 & 10 & (10) & 1,625 & $(1,285)$ & 640 & (625) \\
\hline SD1 & & 30 & (30) & 680 & (680) & 790 & (790) \\
\hline SDA & & 55 & (20) & 1,180 & $(1,025)$ & 525 & (525) \\
\hline SDC & & 50 & (50) & 995 & (995) & 660 & (660) \\
\hline TT & & 50 & (20) & 810 & (310) & 790 & (790) \\
\hline
\end{tabular}

$3 \mathrm{~g} \mathrm{CRR}$ in $21 \mathrm{ml}$ of 0.25 wt. \% $\left(\mathrm{NH}_{4}\right)_{2} \mathrm{SO}_{4} ; 24.5 \mathrm{~h}$.

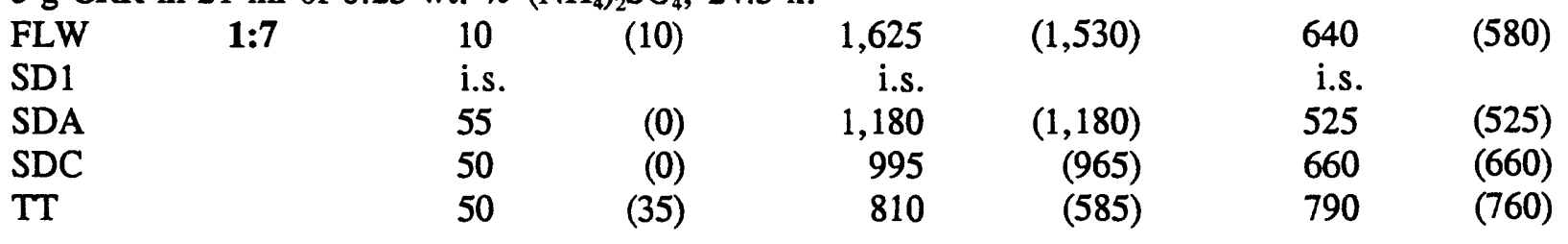


Table 2.-Heavy metals captured and heavy metals remaining (final) in clinoptilolite-rich rocks (CRRs) after laboratory cation-exchange tests using common cations and acids-Continued

\begin{tabular}{|c|c|c|c|c|c|c|}
\hline \multirow[t]{2}{*}{$\overline{C R R}$} & CRR:Exchange & \multicolumn{2}{|c|}{$\mathrm{Cu}$, } & \multirow{2}{*}{ initial $^{\mathbf{Z n},}$} & \multicolumn{2}{|c|}{$\mathbf{P b}$} \\
\hline & Solution & initial & (final) & & initial & (final) \\
\hline
\end{tabular}

Sodium chloride exchanges

$4 \mathrm{~g} \mathrm{CRR}$ in $12 \mathrm{ml}$ of 20.0 wt. \% NaCl; $24 \mathrm{~h}$.

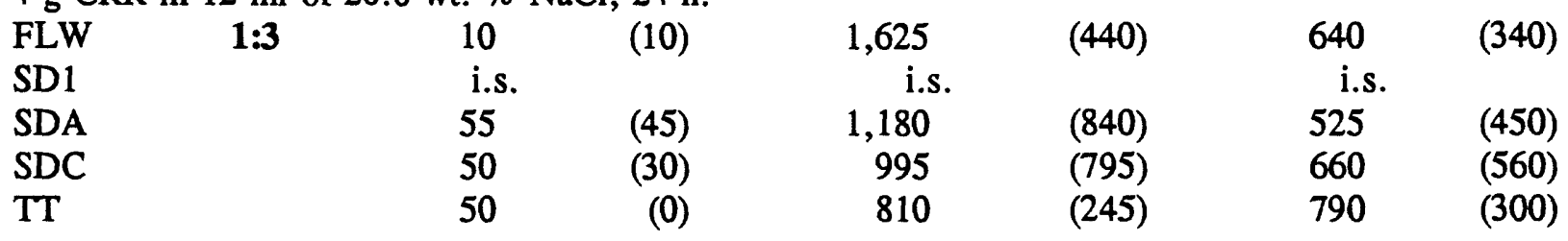

lower California Gulch (6/4/93-6/13/93)

$3 \mathrm{~g} \mathrm{CRR}$ in $9 \mathrm{ml}$ of 25.0 wt. \% NaCl; $47 \mathrm{~h}$.

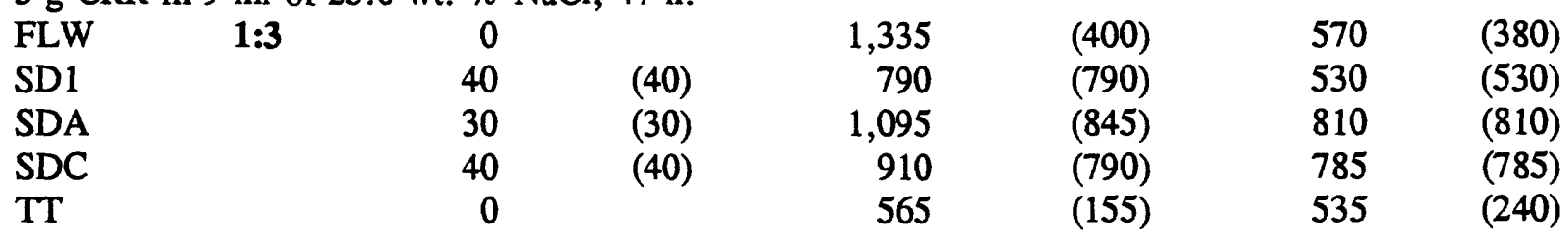

Ammonium exchanges

$3 \mathrm{~g} \mathrm{CRR}$ in $21 \mathrm{ml}$ of 0.25 wt. \% $\left(\mathrm{NH}_{4}\right)_{2} \mathrm{SO}_{4} ; 119 \mathrm{~h}$.

\begin{tabular}{|c|c|c|c|c|c|c|c|}
\hline FLW & 1:7 & 0 & & 1,335 & $(1,295)$ & 570 & (535) \\
\hline SD1 & & 40 & (40) & 790 & (790) & 530 & (530) \\
\hline SDA & & 30 & (30) & 1,095 & $(1,095)$ & 810 & (810) \\
\hline SDC & & 40 & (10) & 910 & $(900)$ & 785 & (785) \\
\hline $\mathrm{TT}$ & & 0 & & 565 & (410) & 535 & (535) \\
\hline
\end{tabular}

Glacial acetic acid exchange

$3 \mathrm{~g} \mathrm{CRR}$ in $30 \mathrm{ml}$ of $\mathrm{pH}=2.6$ glacial acetic acid; $118 \mathrm{~h}$.

\begin{tabular}{|c|c|c|c|c|c|c|}
\hline FLW & $1: 10$ & & 1,335 & $(1,270)$ & 570 & (570) \\
\hline SD1 & 40 & $(0)$ & 790 & (535) & 530 & (530) \\
\hline SDA & 30 & (25) & 1,095 & (745) & 810 & (810) \\
\hline SDC & 40 & $(0)$ & 910 & $(580)$ & 785 & (785) \\
\hline TT & 0 & & 565 & (475) & 535 & (535) \\
\hline
\end{tabular}


Examination of the data in table 3 for the CRRs exposed to the upper Mineral Creek HMPD shows that the 18.2 weight percent $\mathrm{NaCl}$ solution removed most of the $\mathrm{Cu}$ and $\mathrm{Zn}$ from FLW, but only 50 percent of the $\mathrm{Pb}$ was removed. For TT, more than 85 percent of the $\mathrm{Cu}$ and Zn were removed.

In the $\mathrm{pH}=3 \mathrm{HCl}$ exchange, significant amounts of $\mathrm{Cu}, \mathrm{Zn}$, and $\mathrm{Pb}$ were removed from all of the CRRs, except for SDA which retained all of the captured lead.

Table 3.-Heavy metals captured and heavy metals remaining (final) in clinoptilolite-rich rocks (CRRs) after laboratory cation-exchange tests using $\mathrm{NaCl}$ and dilute $\mathrm{HCl}$

[CRR was powdered to minus 100 mesh $(<0.15 \mathrm{~mm})$ ]

\begin{tabular}{|c|c|c|c|c|c|c|c|}
\hline \multirow[t]{2}{*}{ CRR } & \multirow{2}{*}{$\begin{array}{l}\text { CRR:Exchange } \\
\text { Solution }\end{array}$} & \multicolumn{2}{|c|}{$\mathrm{Cu}$, } & \multicolumn{2}{|c|}{ Zn, } & \multicolumn{2}{|c|}{$\mathbf{P b}$} \\
\hline & & initial & (final) & initial & (final) & initial & (final) \\
\hline
\end{tabular}

Upper Mineral Creek (7/14/93-8/10/93)

Sodium chloride exchange

$3 \mathrm{~g} \mathrm{CRR}$ in $18 \mathrm{ml}$ of $18.2 \mathrm{wt} . \% \mathrm{NaCl} ; 22 \mathrm{~h}$.

\begin{tabular}{|c|c|c|c|c|c|c|c|}
\hline FLW & $1: 6$ & 2,420 & (240) & 6,040 & (605) & 145 & (70) \\
\hline SD1 & & 1,205 & $(410)$ & 1,975 & (630) & 210 & (135) \\
\hline SDA & & 1,725 & (330) & 3,395 & (610) & 130 & (105) \\
\hline SDC & & 1,485 & (210) & 2,930 & (555) & 215 & (150) \\
\hline TT & & 815 & (100) & 1,940 & (270) & 135 & (25) \\
\hline
\end{tabular}

Hydrochloric acid exchange

$5 \mathrm{~g} \mathrm{CRR}$ in $25 \mathrm{ml}$ of $\mathrm{pH}=3.0 \mathrm{HCl} ; 24 \mathrm{~h}$.

\begin{tabular}{|c|c|c|c|c|c|c|}
\hline FLW $\quad 1: 5$ & 2,420 & $(2,370)$ & 6,040 & $(5,615)$ & 145 & $(65)$ \\
\hline SD1 & 1,205 & $(1,000)$ & 1,975 & $(1,700)$ & 210 & (155) \\
\hline SDA & 1,725 & $(1,450)$ & 3,395 & $(3,160)$ & 130 & (130) \\
\hline SDC & 1,485 & $(1,275)$ & 2,930 & $(2,400)$ & 215 & (175) \\
\hline TT & 815 & (635) & 1,940 & $(1,610)$ & 135 & (95) \\
\hline
\end{tabular}

Table 4 lists the results for exchange experiments on CRRs exposed to the water in the Rawley mine drain at Bonanza. For the first high and low ammonium sulfate concentration exchanges in table 4, only minor amounts of $\mathrm{Cu}$ and $\mathrm{Zn}$ were removed from the CRRs, except for TT which lost more than 50 percent of the $\mathrm{Zn}$. About 10 percent of the $\mathrm{Pb}$ was removed from one of the CRRs, and this amount could be due to a 10 percent, relative, analytical error.

For the 20 weight percent $\mathrm{NaCl}$ exchanges in table 4 , small amounts of $\mathrm{Cu}, \mathrm{Zn}$, and $\mathrm{Pb}$ were mobilized from all of the CRRs, except for SDA which retained all of the initial $\mathrm{Pb}$. 
In the 30 weight percent ammonium sulfate exchanges shown in table 4, only the SDA and SDC CRRs retained all of the initial $\mathrm{Pb}$, but the other samples lost only small amounts. Large amounts of $\mathrm{Zn}$ and $\mathrm{Cu}$ were lost by FLW and TT.

For the sulfuric acid $\mathrm{pH}=4$ exchange, SDA and SDC retained all of the $\mathrm{Pb}$, but the other CRRs did not. Very little $\mathrm{Cu}$ was removed in this exchange, but FLW and TT lost large amounts of $\mathrm{Zn}$.

In the final 0.25 weight percent ammonium sulfate $\left(675 \mathrm{mg} / \mathrm{L} \mathrm{NH}_{4}^{+}\right)$exchange of table 4 , essentially all of the $\mathrm{Cu}, \mathrm{Zn}$, and $\mathrm{Pb}$ were retained by all of the CRRs.

Table 4.-Heavy metals captured and heavy metals remaining (final) in clinoptilolite-rich rocks (CRRs) after laboratory cation-exchange tests using $\left(\mathrm{NH}_{4}\right)_{2} \mathrm{SO}_{4}, \mathrm{NaCl}$, and dilute $\mathrm{H}_{2} \mathrm{SO}_{4}$

[CRR was powdered to minus 100 mesh $(<0.15 \mathrm{~mm})$. i.s. = insufficient sample]

\begin{tabular}{|c|c|c|c|c|c|c|c|}
\hline \multirow[t]{2}{*}{ CRR } & \multirow{2}{*}{$\begin{array}{l}\text { CRR:Exchange } \\
\text { Solution }\end{array}$} & \multicolumn{2}{|c|}{$\mathrm{Cu}$, } & \multicolumn{2}{|c|}{$\mathrm{Zn}$, } & \multicolumn{2}{|c|}{$\mathbf{P b}$} \\
\hline & & initial & (final) & initial & (final) & initial & (final) \\
\hline
\end{tabular}

Rawley mine tunnel drain at Bonanza (6/17/93-7/15/93)

Ammonium exchanges

$3 \mathrm{~g} \mathrm{CRR}$ on $3 \mathrm{ml}$ of $10.0 \mathrm{wt} . \%\left(\mathrm{NH}_{4}\right)_{2} \mathrm{SO}_{4} ; 24 \mathrm{~h}$.

\begin{tabular}{|c|c|c|c|c|c|c|c|}
\hline FLW & 1:1 & 455 & $(455)$ & 2,770 & $(1,660)$ & 250 & (250) \\
\hline SD1 & & 1,100 & $(1,100)$ & 1,625 & $(1,415)$ & 350 & (320) \\
\hline SDA & & 940 & $(875)$ & 2,180 & $(1,985)$ & 275 & (275) \\
\hline SDC & & 675 & (655) & 1,835 & $(1,595)$ & 255 & (255) \\
\hline TT & & 265 & (150) & 1,415 & (455) & 270 & (270) \\
\hline
\end{tabular}

$2.5 \mathrm{~g} \mathrm{CRR}$ in $25 \mathrm{ml}$ of 0.5 wt. $\%\left(\mathrm{NH}_{4}\right)_{2} \mathrm{SO}_{4} ; 68 \mathrm{~h}$.

\begin{tabular}{|c|c|c|c|c|c|c|c|}
\hline FLW & 1:10 & 455 & $(440)$ & 2,770 & $(2,550)$ & 250 & (250) \\
\hline SD1 & & 1,100 & $(1,100)$ & 1,625 & $(1,495)$ & 350 & (350) \\
\hline SDA & & 940 & (865) & 2,180 & $(2,025)$ & 275 & (270) \\
\hline SDC & & 675 & (675) & 1,835 & $(1,580)$ & 255 & (255) \\
\hline TT & & 265 & (250) & 1,415 & $(650)$ & 270 & (270) \\
\hline
\end{tabular}

Sodium chloride exchanges

$4 \mathrm{~g} \mathrm{CRR}$ in $12 \mathrm{ml}$ of $20.0 \mathrm{wt}$. \% NaCl: $24 \mathrm{~h}$.

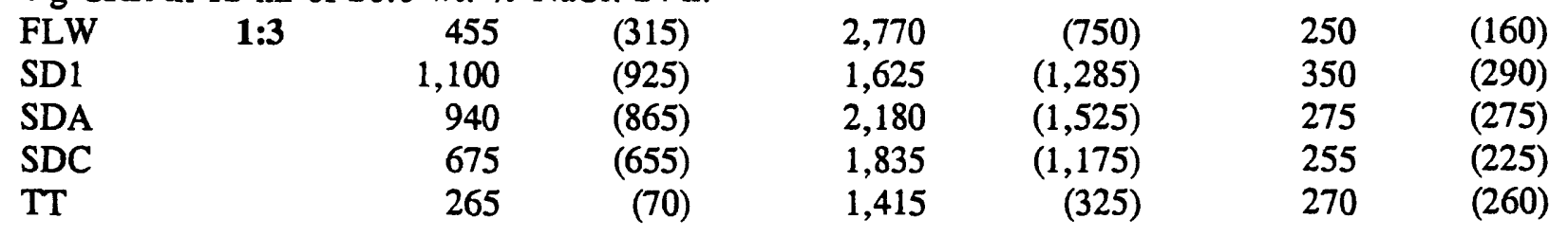


Table 4.-Heavy metals captured and heavy metals remaining (final) in clinoptilolite-rich rocks (CRRs) after laboratory cation-exchange tests using $\left(\mathrm{NH}_{4}\right)_{2} \mathrm{SO}_{4}, \mathrm{NaCl}$, and dilute $\mathrm{H}_{2} \mathrm{SO}_{4}$-Continued

\begin{tabular}{cccccc}
\hline CRR & $\begin{array}{c}\text { CRR:Exchange } \\
\text { Solution }\end{array}$ & initial & $\mathrm{Cu}$, & $\mathrm{Zn}$, & Pb, \\
(final) & initial & (final) & initial
\end{tabular}

Rawley mine tunnel drain at Bonanza $(7 / 15 / 93-8 / 11 / 93)$

Ammonium and acid sulfate exchanges

$3 \mathrm{~g} \mathrm{CRR}$ in $9 \mathrm{ml}$ of 30.0 wt. \% $\left(\mathrm{NH}_{4}\right)_{2} \mathrm{SO}_{4} ; 70 \mathrm{~h}$.

\begin{tabular}{|c|c|c|c|c|c|c|}
\hline FLW & $1: 3 \quad 355$ & (195) & 2,560 & (385) & 345 & (315) \\
\hline SD1 & & i.s. & \multicolumn{2}{|c|}{ i.s. } & \multicolumn{2}{|c|}{ i.s. } \\
\hline SDA & 775 & (775) & 1,955 & $(1,725)$ & 280 & (280) \\
\hline SDC & 825 & (620) & 1,815 & $(1,525)$ & 285 & (285) \\
\hline $\mathrm{TT}$ & 215 & (120) & 1,250 & (210) & 320 & (315) \\
\hline
\end{tabular}

$3 \mathrm{~g} \mathrm{CRR}$ in $15 \mathrm{ml}$ of $\mathrm{pH}=4.0, \mathrm{H}_{2} \mathrm{SO}_{4} ; 90 \mathrm{~h}$.

$\begin{array}{llrrrrrr}\text { FLW } & 1: 5 & 355 & (355) & 2,560 & (410) & 345 & (200) \\ \text { SD1 } & & & & & & & \\ \text { i.s. } & & & \text { i.s. } & \\ \text { SDA } & & 775 & (775) & 1,955 & (1,330) & 280 & (280) \\ \text { SDC } & & 825 & (785) & 1,815 & (1,090) & 285 & (285) \\ \text { TT } & & 215 & (215) & 1,250 & (110) & 320 & (80)\end{array}$

$3 \mathrm{~g} \mathrm{CRR}$ in $15 \mathrm{ml}$ of $0.25 \mathrm{wt} . \%\left(\mathrm{NH}_{4}\right)_{2} \mathrm{SO}_{4} ; 90 \mathrm{~h}$.

$\begin{array}{llllllll}\text { FLW } & 1: 5 & 355 & (355) & 2,560 & (2,560) & 345 & (345) \\ \text { SD1 } & & \text { i.s. } & & & \text { i.s. } & & \\ \text { SDA } & & 775 & (775) & 1,955 & (1,955) & 280 & (280) \\ \text { SDC } & & 825 & (825) & 1,815 & (1,815) & 285 & (285) \\ \text { TT } & & 215 & (215) & 1,250 & (1,115) & 320 & (315)\end{array}$

Figure 4 shows the percentages of $\mathrm{Zn}$ remaining in the HMPD-exposed CRRs after the 19 $\mathrm{NaCl}$ exchange experiments listed in tables 2, 3, and 4. For rock:water ratios of $1: 3$, the SD CRRs all retained more than 60 percent of the $\mathrm{Zn}$, whereas the FLW and TT CRRs retained between 20 and 30 percent of the $\mathrm{Zn}$. For the rock:water ratios of 1:6, all of the CRRs retained less than 35 percent of the $\mathrm{Zn}$.

Figure 5 shows the percentage of $\mathrm{Pb}$ remaining in the HMPD-exposed CRRs after the 19 $\mathrm{NaCl}$ exchange experiments listed in tables 2, 3, and 4. For rock:water ratios of $1: 3$, the SD CRRs retained 80 to 100 percent of the $\mathrm{Pb}$, while the FLW and TT CRRs retained only 38 to 68 percent of the $\mathrm{Pb}$. For rock:water ratios of 1:6, all the CRRs retained only 18 to 81 percent of the $\mathrm{Pb}$; however, the amounts of $\mathrm{Pb}$ captured initially were less than $275 \mathrm{ppm}$ (fig. 5). 
18-25 wt. \% NaCl exchanges

vs. initial Zn concentrations

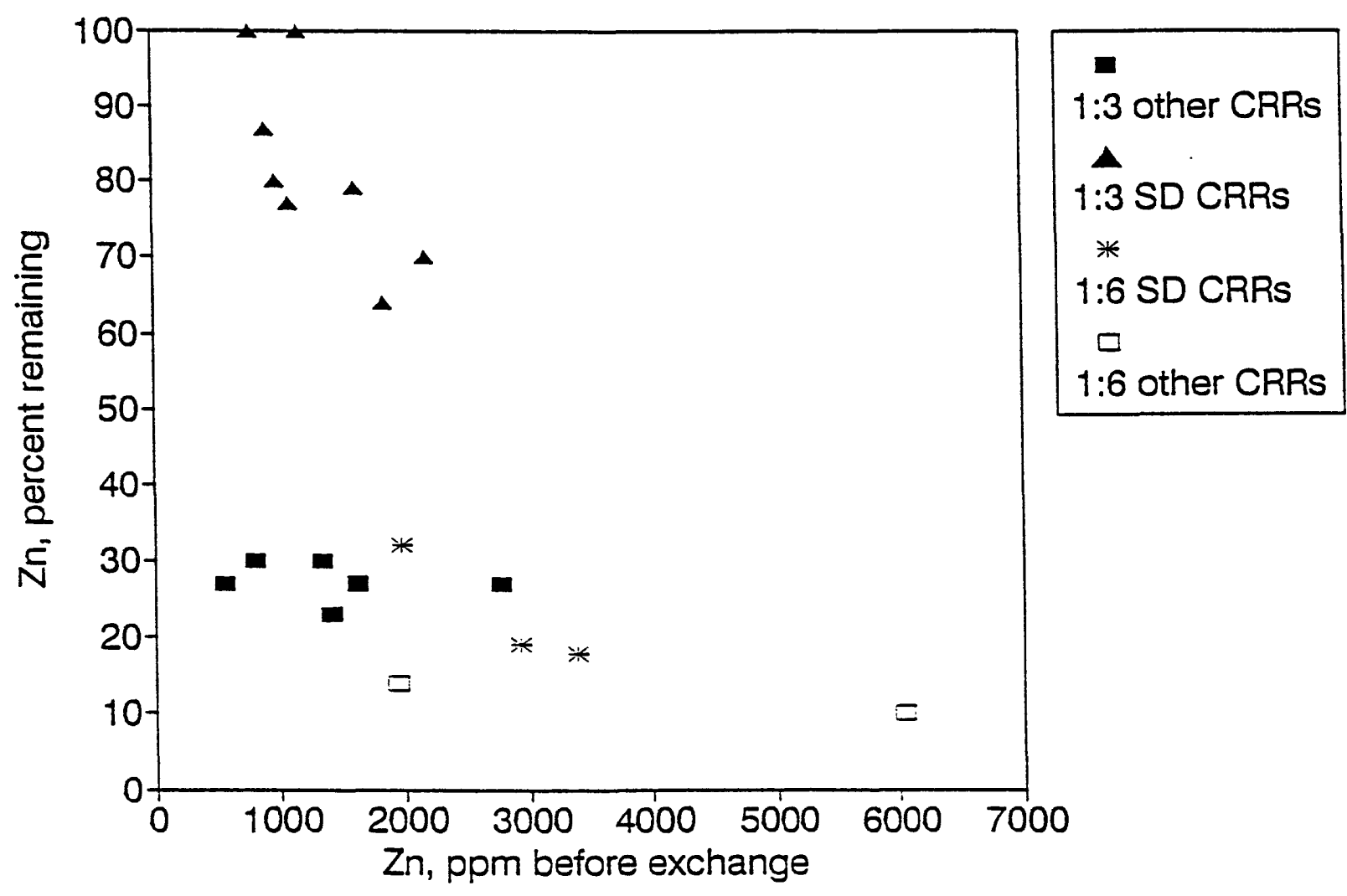

Figure 4. - Concentrations of zinc in clinoptilolite-rich rocks (CRRs) before sodium chloride exchanges versus the percentage remaining after the exchange. SD refers to South Dakota samples. Data from tables 2, 3, and 4. 


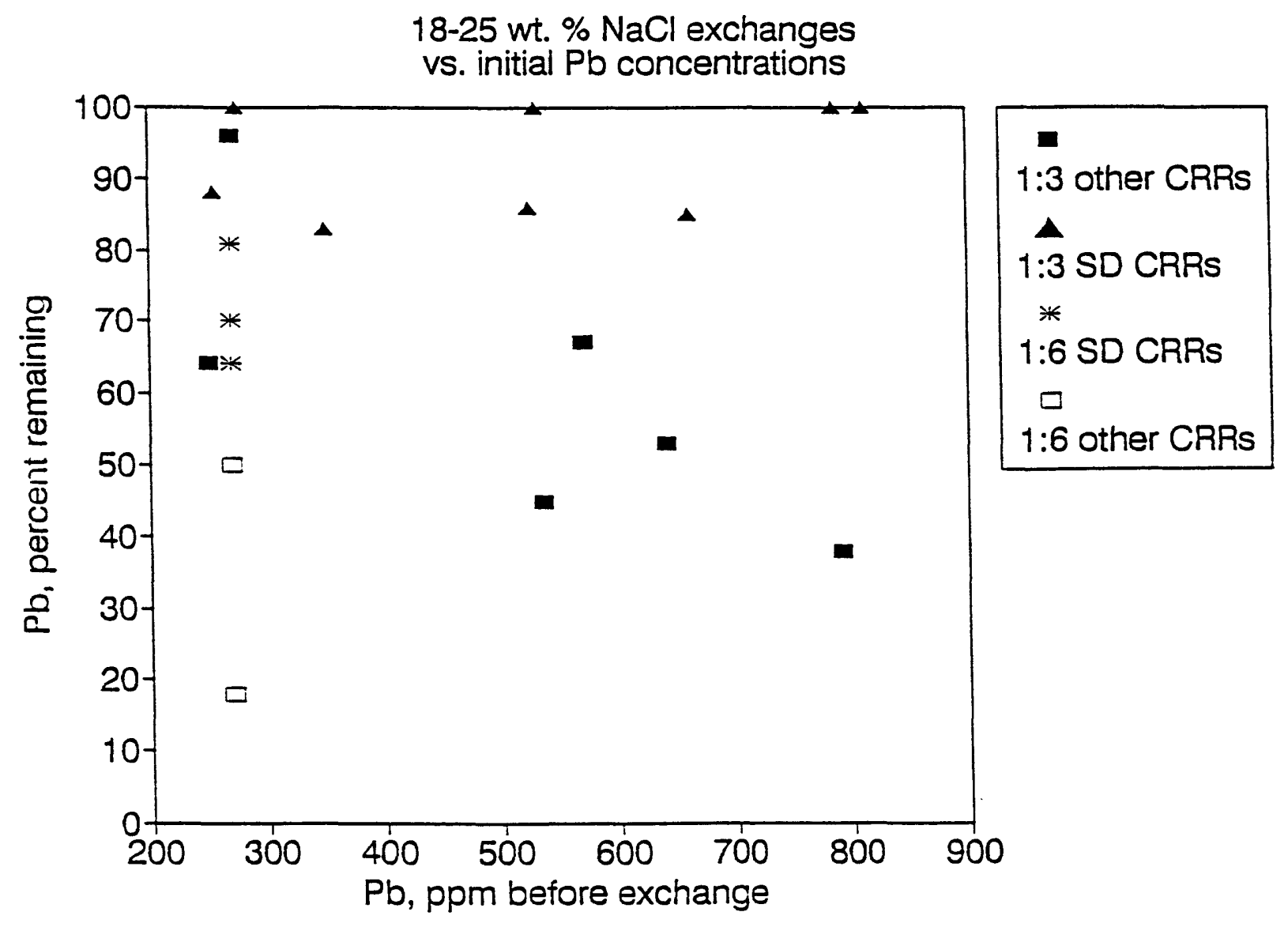

Figure 5.-Concentrations of lead in clinoptilolite-rich rocks (CRRs) before sodium chloride exchange versus the percentage of lead remaining after the exchange. SD refers to South Dakota samples. Data from tables 2, 3, and 4. 
Table 5 shows the results for 24 exchange experiments for CRR samples exposed to the Wellington drain, which is chiefly contaminated by $\mathrm{Zn}$ and $\mathrm{Pb}$. In the initial 18 weight percent $\mathrm{NaCl}$ exchange, different amounts of $\mathrm{Zn}$ were exchanged out of all the CRRs; all of the $\mathrm{Pb}$ remained in all but three CRRs.

In the 10 weight percent $\mathrm{NaCl}$ solution with $\mathrm{pH}=2.6$, considerable amounts of $\mathrm{Zn}$ were exchanged, but $\mathrm{Pb}$ remained unchanged for CCO, FCEN, HLO, SDA, and SVO. FLW lost the greatest amounts of both $\mathrm{Zn}$ and $\mathrm{Pb}$.

For the third set of experiments in table 5, the 10 weight percent $\mathrm{NaCl}$ solution had no influence on the $\mathrm{Pb}$ concentrations of the CRRs, but 57 percent of $\mathrm{Zn}$ was exchanged by FLW.

Table 5.-Heavy metals captured and heavy metals remaining (final) in clinoptilolite-rich rocks (CRRs) after laboratory cation-exchange tests using $\mathrm{NaCl}$ and acidified- $\mathrm{NaCl}$ solutions

[CRR was powdered (95\% minus 100 mesh)]

\begin{tabular}{|c|c|c|c|c|c|}
\hline CRR & $\begin{array}{c}\text { CRR:Exchange } \\
\text { Solution }\end{array}$ & initial & (final) & initial & (final) \\
\hline
\end{tabular}

Wellington mine drain near Breckenridge (7/20/93-8/13/93)

$5 \mathrm{~g} \mathrm{CRR}$ in $25 \mathrm{ml}$ of $18.0 \mathrm{wt} . \% \mathrm{NaCl} ; 119 \mathrm{~h}$.

\begin{tabular}{|c|c|c|c|c|}
\hline $\mathrm{CCO}$ & 1,630 & $(715)$ & 210 & (210) \\
\hline FCEN & 1,470 & $(750)$ & 120 & (120) \\
\hline FCWN & 1,510 & $(1,010)$ & 195 & (195) \\
\hline FLW & 3,900 & $(1,130)$ & 240 & (240) \\
\hline HLO & 1,870 & $(1,365)$ & 305 & (305) \\
\hline $\mathrm{PBC}$ & 1,560 & $(750)$ & 220 & (220) \\
\hline SDA & 3,720 & $(3,460)$ & 335 & (335) \\
\hline SVO & 2,505 & $(1,300)$ & 345 & (345) \\
\hline
\end{tabular}

$5 \mathrm{~g} \mathrm{CRR}$ in $25 \mathrm{ml}$ of $10.0 \mathrm{wt} . \% \mathrm{NaCl}$, at $\mathbf{p H}=2.6(\mathrm{HCl}) ; 120 \mathrm{~h}$.

\begin{tabular}{|c|c|c|c|c|}
\hline $\mathrm{CCO}$ & 1,630 & $(605)$ & 210 & (210) \\
\hline FCEN & 1,470 & (575) & 120 & (120) \\
\hline FCWN & 1,510 & (650) & 195 & (180) \\
\hline FLW & 3,900 & $(1,055)$ & 240 & (180) \\
\hline HLO & 1,870 & $(1,200)$ & 305 & (305) \\
\hline PBC & 1,560 & (595) & 220 & (200) \\
\hline SDA & 3,720 & $(3,535)$ & 335 & (335) \\
\hline SVO & 2,505 & $(1,025)$ & 345 & (345) \\
\hline
\end{tabular}

$5 \mathrm{~g} \mathrm{CRR}$ in $35 \mathrm{ml}$ of $10.0 \mathrm{wt}$. \% $\mathrm{NaCl} ; 24.5 \mathrm{~h}$.

\begin{tabular}{|c|c|c|c|c|}
\hline $\mathrm{CCO}$ & 1,630 & $(1,010)$ & 210 & (210) \\
\hline FCEN & 1,470 & (940) & 120 & (120) \\
\hline FCWN & 1,510 & $(1,195)$ & 195 & (195) \\
\hline FLW & 3,900 & $(1,675)$ & 240 & (240) \\
\hline HLO & 1,870 & $(1,610)$ & 305 & (305) \\
\hline $\mathrm{PBC}$ & 1,560 & (965) & 220 & (220) \\
\hline SDA & 3,720 & $(3,385)$ & 335 & (335) \\
\hline SVO & 2,505 & $(1,605)$ & 345 & (345) \\
\hline
\end{tabular}




\section{SECONDARY EXCHANGES IN NEAR-SATURATED NaCl REGENERANT SOLUTIONS}

The final CRR tests were done using 25 weight percent $\mathrm{NaCl}$ solutions in a CRR:exchange solution ratio of $1: 3$. All CRR samples were powders $(95 \%<0.15 \mathrm{~mm})$ so that exchange reactions would be rapid. All exchange periods were 71.5 or $72 \mathrm{~h}$ with exchange media at rest. The $\mathrm{pH}$ of each of these solutions was measured once each day during the experiments. The near-saturated $\mathrm{NaCl}$ solution is here called the regenerant solution, inasmuch as captured heavy metals that are displaced from the CRRs become dissolved, and the CRRs are, ideally, regenerated to become free of captured heavy metals (Schultz and Zamzow, 1993). This process occurs with some CRRs but not others. Only three of the best performing CRRs (of the six tested side-by-side for heavy-metal capture in the HMPDs) were selected for the final laboratory exchange studies. This subset of CRRs was chosen because these CRRs were at least 50 percent better at capturing metals than the other CRRs tested (Desborough, 1994).

For all the results presented in tables $6,7,8$, and 9 , the exchanges presented in each table were done simultaneously using five grams of CRR and $15 \mathrm{ml}$ of each exchange solution.

Table 6 shows that raw FLW captured the most $\mathrm{Cu}$ and $\mathrm{Zn}$ in the Argo tunnel drain; this $\mathrm{CRR}$ also had the overall highest exchange of combined $\mathrm{Cu}+\mathrm{Zn}$ in the 25 weight percent $\mathrm{NaCl}$ regenerant solution. Most of the CRRs exchanged between 86 to 92 percent of $\mathrm{Cu}+\mathrm{Zn}$; however, the SDA CRR exchanged 42 to 54 percent of the $\mathrm{Zn}$ but none of the $\mathrm{Cu}$. The final pH of the NaCl-regenerant solution for most of the CRRs was 3.1 to 3.6, but for the SDA CRRs the range was 5.1 to 5.4 because of their greater preference for $\mathrm{H}^{+}$over $\mathrm{Na}^{+}$.

Table 6.-Results of 25 weight percent $\mathrm{NaCl}$ exchanges for the three best performing clinoptiloliterich rocks (CRRs) for heavy-metal capture in the Argo tunnel drain, Idaho Springs, Colorado

[Dwell time was 71.5 hours for all three sets. Both initial and final metal concentrations are given. Initial and final exchange solution $\mathrm{pH}$ are also given]

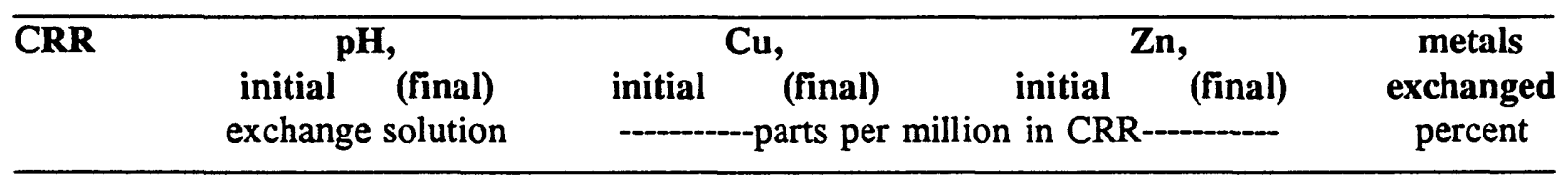

Set 1, Argo (10/27/93-11/4/93)

$\begin{array}{llllllll}\text { ACT } & 8.1 & (3.6) & 130 & (5) & 730 & (65) & 92 \\ \text { CHI } & 8.1 & (3.3) & 120 & (0) & 755 & (70) & 92 \\ \text { FLW } & 8.1 & (3.3) & 160 & (40) & 970 & (70) & 89\end{array}$

Set 2, Argo (11/4/93-11/12/93)

$\begin{array}{lrrrrrrr}\text { FCEN } & 8.1 & (3.6) & 20 & (0) & 245 & (20) & 92 \\ \text { FLW } & 8.1 & (3.3) & 85 & (5) & 850 & (85) & 90 \\ \text { SDA } & 8.1 & (5.4) & 105 & (105) & 625 & (360) & 36\end{array}$

Set 3, Argo (12/2/93-12/10/93)

$\begin{array}{lrrrrrrr}\text { FLW } & 8.1 & (3.5) & 150 & (25) & 900 & (70) & 91 \\ \text { SDA } & 8.1 & (5.1) & 95 & (95) & 635 & (295) & 47 \\ \text { SVO } & 8.1 & (3.1) & 110 & (10) & 420 & (65) & 86\end{array}$


Table 7 gives the results for the 25 weight percent $\mathrm{NaCl}$ laboratory exchanges for those raw CRRs that captured the most heavy metals at the lower and upper California Gulch test sites in 1993 (Desborough, 1994). Although the laboratory test period was only $72 \mathrm{~h}$, the results indicate that less than about 50 percent of the heavy metals were exchanged (table 7), except for FLW of the upper California Gulch test where 72 percent of the metals were exchanged.

Table 7.-Results of 25 weight percent $\mathrm{NaCl}$ exchanges for the three best performing clinoptilolite-rich rocks (CRRs) for heavy-metal capture for three tests in lower California Gulch and one test in upper California Gulch

[All exchanges were for $72 \mathrm{~h}$ at rest]

\begin{tabular}{llllll}
\hline CRR & \multicolumn{2}{c}{$\mathbf{C u}$} & \multicolumn{2}{c}{$\mathrm{Zn}$} & \multicolumn{2}{c}{ Pb } & metals \\
& initial $^{\text {(final) }}$ & initial $_{\text {(final) }}^{\text {initial }}$ & (final) & $\begin{array}{c}\text { exchanged } \\
\text { percent }\end{array}$ \\
\hline
\end{tabular}

\begin{tabular}{|c|c|c|c|c|c|c|c|}
\hline \multirow[b]{2}{*}{ FLW } & \multicolumn{6}{|c|}{ Set 1. lower California Gulch $(6 / 13 / 93-7 / 2 / 93)$} & \multirow[b]{2}{*}{44} \\
\hline & 0 & (0) & 1,300 & $(680)$ & 210 & (170) & \\
\hline SD1 & 55 & (30) & 1,360 & $(1,310)$ & 165 & (165) & 5 \\
\hline \multirow[t]{2}{*}{ SDC } & 0 & (0) & 1,190 & $(1,030)$ & 175 & (150) & 14 \\
\hline & \multicolumn{6}{|c|}{ Set 2. lower California Gulch $(7 / 20 / 93-8 / 3 / 93)$} & \\
\hline $\mathrm{CCO}$ & 0 & (0) & 1,400 & $(1,020)$ & 40 & (40) & 26 \\
\hline SDA & 0 & (0) & 2,130 & $(1,900)$ & 50 & (25) & 12 \\
\hline svo & 0 & (0) & 1,945 & $(1,330)$ & 110 & (110) & 30 \\
\hline \multicolumn{8}{|c|}{ Set 3. lower California Gulch (10/16/93-10/28/93) } \\
\hline FLW & 0 & (0) & 1,095 & (695) & 20 & $(0)$ & 32 \\
\hline ACT & 0 & (0) & 995 & (535) & 30 & (30) & 45 \\
\hline SDA & 0 & (0) & 1,165 & $(1,080)$ & 65 & (20) & 11 \\
\hline \multicolumn{8}{|c|}{ upper California Gulch (5/29/93-6/4/93) } \\
\hline FLW & 40 & (0) & 1,295 & (200) & 415 & (255) & 74 \\
\hline SDA & 60 & (55) & 950 & (750) & 460 & (430) & 16 \\
\hline SDC & 65 & (65) & 795 & (470) & 435 & (385) & 29 \\
\hline
\end{tabular}

Table 8 shows the results for 25 weight percent $\mathrm{NaCl}$ laboratory exchanges of the three best performing CRRs tested for heavy-metal capture at upper Mineral Creek and two tests at the Rawley tunnel at Bonanza. For CRRs tested at the upper Mineral Creek site, 81 to 89 percent of the $\mathrm{Cu}+\mathrm{Zn}+\mathrm{Pb}$ were removed. For the six tests of Rawley tunnel exposed CRRs, less than 70 percent of the $\mathrm{Cu}+\mathrm{Zn}+\mathrm{Pb}$ were removed.

Table 9 shows the results for 25 weight percent laboratory exchanges for the three best performing CRRs for heavy-metal capture for samples exposed during two tests at the Wellington mine drain. For all six tests, less than 70 percent of the metals were removed, and for the SDA and SDC samples, only 16 to 20 percent of the metals were removed. 
Table 8. - Results of 25 weight percent $\mathrm{NaCl}$ exchanges for the three best performing clinoptiloliterich rocks (CRRs) for heavy-metal capture in upper Mineral Creek and the Rawley tunnel at Bonanza

[All exchanges were for $72 \mathrm{~h}$ at rest]

\begin{tabular}{|c|c|c|c|c|c|c|c|}
\hline \multirow[t]{2}{*}{$\overline{\mathrm{CRR}}$} & \multicolumn{2}{|c|}{$\mathrm{Cu}$} & \multicolumn{2}{|c|}{$\mathbf{Z n}$} & \multicolumn{2}{|c|}{$\mathbf{P b}$} & \multirow{2}{*}{$\begin{array}{c}\text { metals } \\
\text { exchanged } \\
\text { percent }\end{array}$} \\
\hline & initial & (final) & initial & (final) & initial & (final) & \\
\hline \multicolumn{8}{|c|}{ upper Mineral Creek (8/10/93-10/27/93) } \\
\hline FLW & 2,550 & $(365)$ & 5,580 & (485) & 220 & (110) & 89 \\
\hline SDA & 1,755 & (495) & 3,530 & (390) & 175 & $(100)$ & 82 \\
\hline SVO & 2,000 & (355) & 2,670 & (480) & 280 & (110) & 81 \\
\hline \multicolumn{8}{|c|}{ Rawley/Bonanza (6/12/93-6/17/93) } \\
\hline FLW & 370 & $(340)$ & 2,415 & $(475)$ & 190 & (115) & 69 \\
\hline SDA & 720 & (715) & 2,315 & $(1,070)$ & 130 & (130) & 39 \\
\hline SDC & 765 & (710) & 1,475 & $(1,045)$ & 135 & (135) & 20 \\
\hline \multicolumn{8}{|c|}{ Rawley/Bonanza (10/16/93-10/28/93) } \\
\hline $\mathrm{CHI}$ & 205 & $(135)$ & 940 & $(440)$ & 145 & $(60)$ & 51 \\
\hline FLW & 295 & (275) & 2,305 & (525) & 145 & $(100)$ & 67 \\
\hline SDA & 660 & (575) & 1,900 & $(1,170)$ & 130 & $(125)$ & 30 \\
\hline
\end{tabular}

Table 9.-Results of 25 weight percent $\mathrm{NaCl}$ exchanges for the three best performing clinoptilolite-rich rocks (CRRs) for heavy-metal capture in the Wellington mine drain

[All exchanges were for $72 \mathrm{~h}$ at rest. No $\mathrm{Cu}$ was captured]

\begin{tabular}{|c|c|c|c|c|c|}
\hline \multirow[t]{2}{*}{$\overline{\text { CRR }}$} & \multicolumn{2}{|c|}{$\mathbf{Z n}$} & \multicolumn{2}{|c|}{$\mathbf{P b}$} & \multirow{2}{*}{$\begin{array}{c}\text { metals } \\
\text { exchanged } \\
\text { percent }\end{array}$} \\
\hline & initial & (final) & initial & (final) & \\
\hline \multicolumn{6}{|c|}{$5 / 28 / 94-6 / 4 / 94$} \\
\hline FLW & 3,315 & $(1,330)$ & 215 & (195) & 57 \\
\hline SDA & 3,030 & $(2,422)$ & 190 & $(165)$ & 20 \\
\hline SDC & 2,700 & $(2,235)$ & 195 & (190) & 16 \\
\hline \multicolumn{6}{|c|}{$10 / 16 / 94-10 / 28 / 94$} \\
\hline $\mathrm{CHI}$ & 2,585 & (715) & 180 & $(165)$ & 68 \\
\hline FLW & 3,260 & $(1,170)$ & 225 & (190) & 61 \\
\hline SDA & 2,640 & $(2,185)$ & 155 & $(155)$ & 16 \\
\hline
\end{tabular}




\section{DISCUSSION OF RESULTS}

The exchange data were evaluated to explain the wide range of extractability observed in the cation exchange experiments. The HMPD-exposed CRRs for the $25 \% \mathrm{NaCl}$ exchanges of tables $6,7,8$, and 9 were treated identically in the laboratory; therefore the different amounts of $\mathrm{Cu}, \mathrm{Zn}$, and $\mathrm{Pb}$ remaining in these CRRs after exchange must be due to some factor or factors independent of laboratory conditions. One significant factor is the $\mathrm{pH}$ of the HMPD to which the raw CRRs were exposed. The term "mean $\mathrm{pH}$," for the purposes of this report, represents the average of the $\mathrm{pH}$ of the water at the sample site at the time of CRR immersion and at the time of sample removal (Desborough, 1994), as continuous $\mathrm{pH}$ monitoring was not done.

Figure 6 shows the percentage of $\mathrm{Cu}$ remaining in 24 CRRs after exchange in 25 weight percent $\mathrm{NaCl}$ solutions versus the mean $\mathrm{pH}$ of the sample site in the HMPD. For nine of the 11 exchange experiments that used SD CRRs, the CRRs retained more than 85 percent of the $\mathrm{Cu}$; in the other tests, it retained 55 percent and 28 percent. All of the other CRRs retained 25 percent or less of the $\mathrm{Cu}$, except for two FLW samples from sample sites with pH's of 6 and 7, which retained 66 and 92 percent of $\mathrm{Cu}$, respectively.

Figure 7 shows the percentage of $\mathrm{Zn}$ remaining in $36 \mathrm{CRRs}$ after exchange in 25 weight percent $\mathrm{NaCl}$ solutions versus the mean $\mathrm{pH}$ of the sample site. There are two distinct groups of data. One group retained between 46 and 96 percent of the $\mathrm{Zn}$. All of these are samples of the SD CRRS. With one exception ( 46 percent $\mathrm{Zn}$ retained and $\mathrm{pH}=7.1$ ), all of the CRRs from other localities retained less $\mathrm{Zn}$ than the SD CRRs. It is noteworthy that the two groups plot with an apparent positive relationship between increasing $\mathrm{pH}$ of the HMPD water and the amount of $\mathrm{Zn}$ retained after the 25 weight percent $\mathrm{NaCl}$ exchange.

Figure 8 shows the percentage of $\mathrm{Pb}$ remaining in $22 \mathrm{CRRs}$ after exchange in the $\mathrm{NaCl}$ solutions versus the mean $\mathrm{pH}$ of the sample site. Those CRRs that captured less than $100 \mathrm{ppm}$ of $\mathrm{Pb}$ from the water are not shown because of the poor precision of the $\mathrm{Pb}$ analysis. Eleven of the 12 SD CRRs retained more than 85 percent of the captured $\mathrm{Pb}$; one with $175 \mathrm{ppm}$ of $\mathrm{Pb}$ retained only 57 percent. Eight FLW CRRs retained between 41 and 91 percent of the $\mathrm{Pb}$. Two other CRRs, CHI and SVO, retained 92 percent and 39 percent of the $\mathrm{Pb}$, respectively.

Figure 9 shows the percentage of $\mathrm{Cu}+\mathrm{Zn}+\mathrm{Pb}$ remaining for $36 \mathrm{CRRs}$ after exchange in 25 weight percent $\mathrm{NaCl}$ solutions versus the mean $\mathrm{pH}$ of the sample sites. Two groups of CRRs are again recognizable. The 13 CRRs of the upper group are all SD samples; however, two SD CRR samples plot in the lower group of other CRRs. Some correlation exists between the mean $\mathrm{pH}$ of the HMPD water and the amounts of heavy metals retained after exposure to 25 weight percent $\mathrm{NaCl}$ solutions. It is clear that the SD CRRs generally retain more $\mathrm{Cu}, \mathrm{Zn}$, and $\mathrm{Pb}$ than the other CRRs after exposure to nearly saturated $\mathrm{NaCl}$ solutions.

The stronger preference of the South Dakota CRRs for $\mathrm{H}^{+}$, compared to CRRs from three other deposits, was demonstrated by Desborough (1993, figs. 1, 2, and 3) in laboratory studies that used serial exposures of each $\mathrm{CRR}$ to acidic and then $\mathrm{NaCl}$-saturated solutions of neutral $\mathrm{pH}$. This same $\mathrm{H}^{+}$preference of the SD CRRs is observed in this study.

Figure 10 contrasts the SD CRRs and the other CRRs regarding the mean $\mathrm{pH}$ of the HMPD water and the final $\mathrm{pH}$ of the $\mathrm{NaCl}$ exchange solution. The initial $\mathrm{pH}$ of all 36 of the 25 percent $\mathrm{NaCl}$ exchange solutions was 8.1. For most of the 25 percent $\mathrm{NaCl}$ exchange experiments for SD CRRs, the final $\mathrm{pH}$ of the exchange solutions was significantly higher than the exchange solutions of the other CRRs (fig. 10). Regression analysis yields an $R^{2}=0.91$ $(n=21)$ for the "other CRRs" shown on figure 10 ; the $R^{2}$ value for the "SD CRRs" is only 0.52 $(\mathrm{n}=15)$. 
$\%$ Cu remaining after $25 \% \mathrm{NaCl}$ exchange versus mean $\mathrm{pH}$ of HMPD water

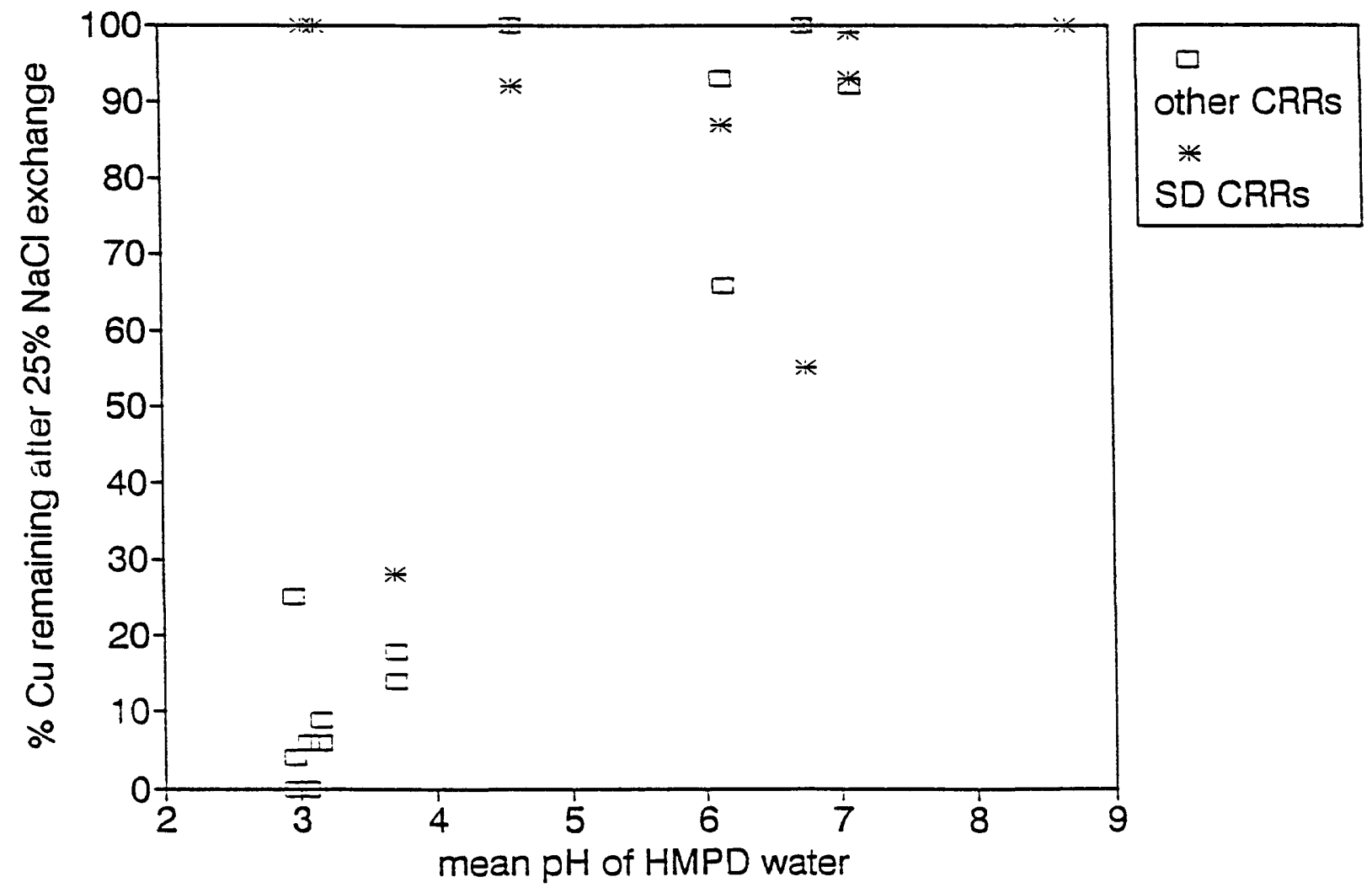

Figure 6.-Relations of the mean $\mathrm{pH}$ of the heavy-metal-polluted drainage (HMPD) of metal capture versus the amount of copper remaining in clinoptilolite-rich rocks (CRRs) after 25 weight percent $\mathrm{NaCl}$ exchange. SD refers to South Dakota samples. 


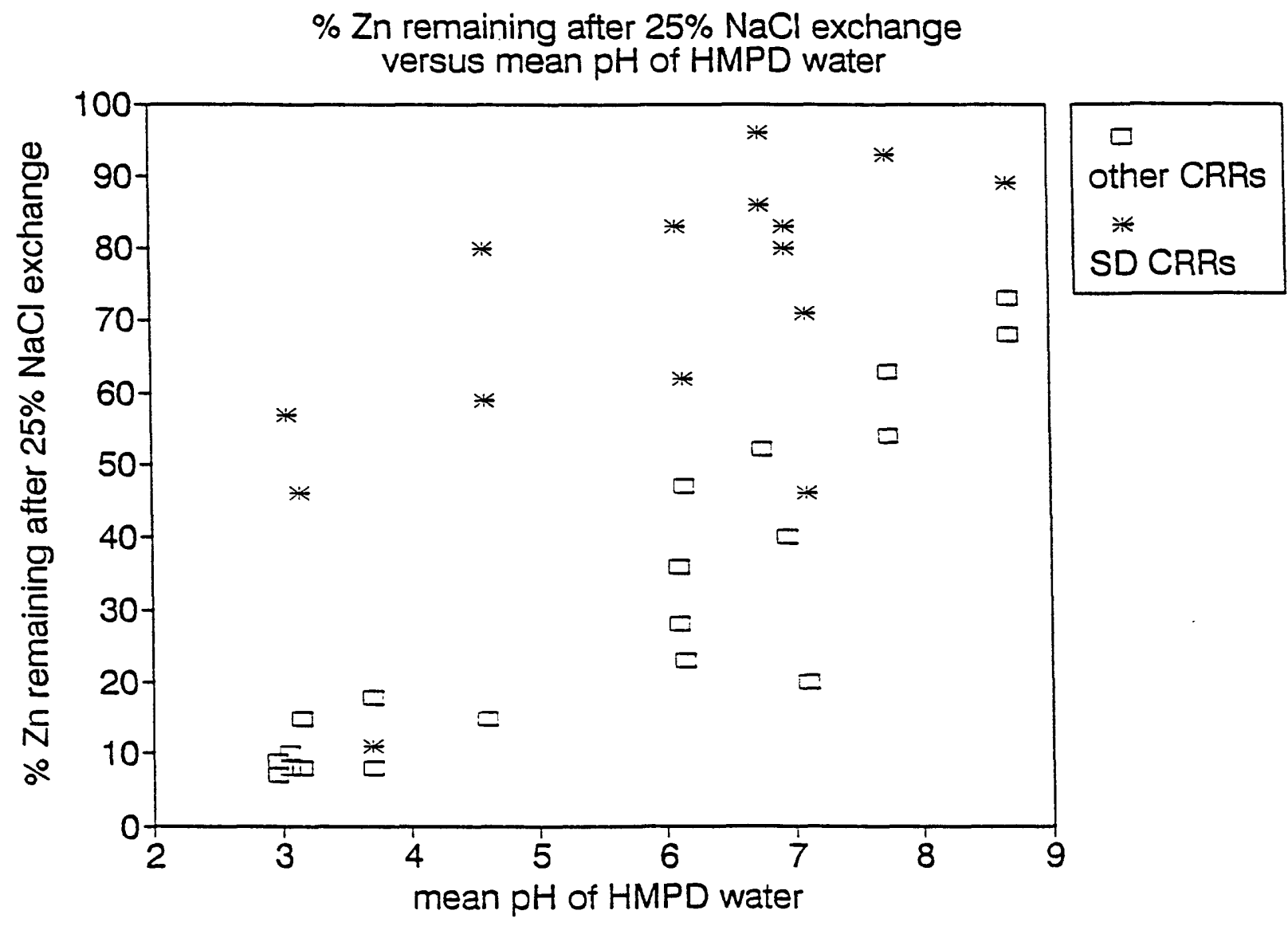

Figure 7.-Relations of the mean pH of the heavy-metal-polluted drainage (HMPD) of metal capture versus the amount of zinc remaining in clinoptilolite-rich rocks (CRRs) after 25 weight percent $\mathrm{NaCl}$ exchange. SD refers to South Dakota samples. 


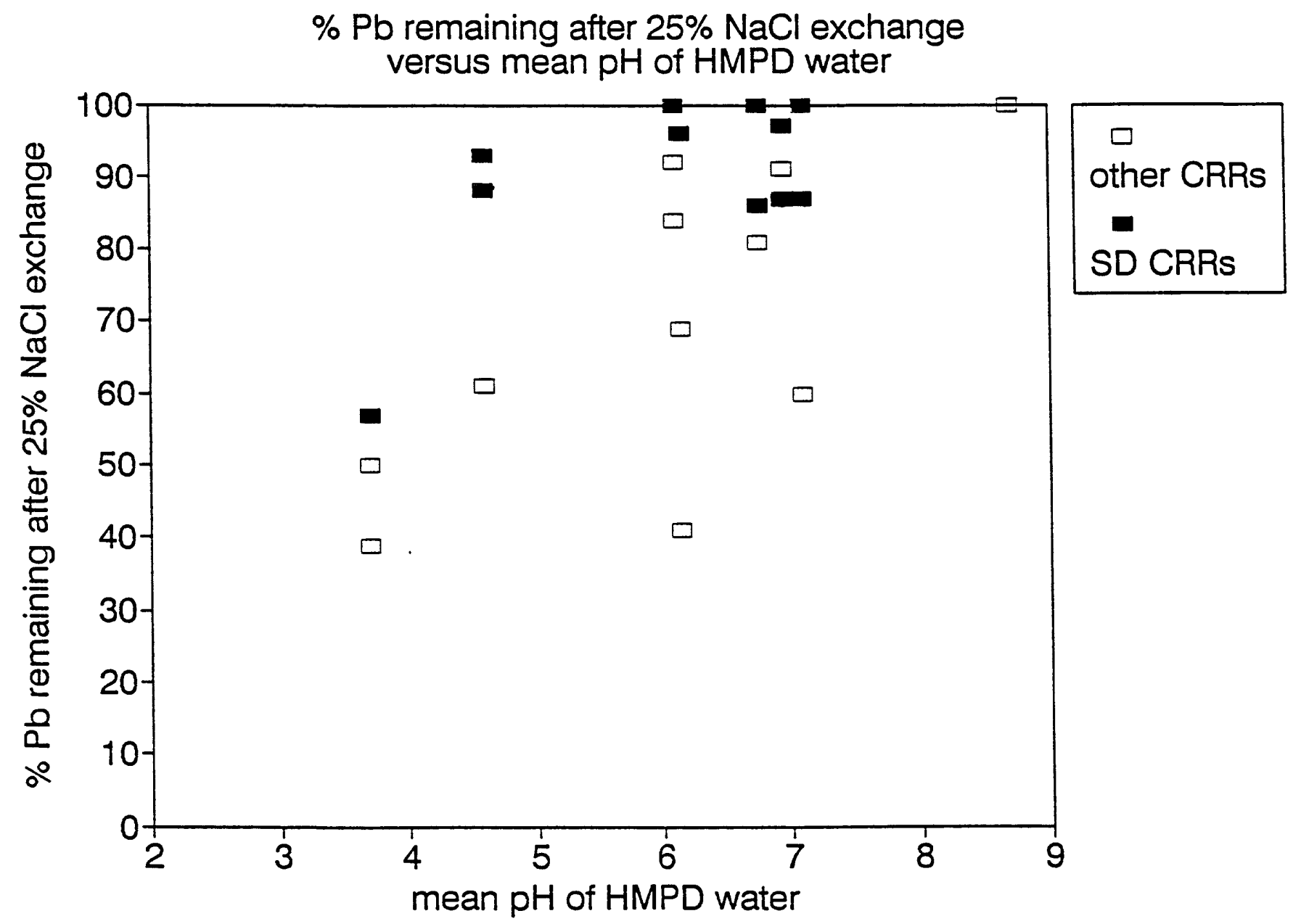

Figure 8.-Relations of the mean $\mathrm{pH}$ of the heavy-metal-polluted drainage (HMPD) of metal capture versus the amount of lead remaining in clinoptilolite-rich rocks (CRRs) after 25 weight percent $\mathrm{NaCl}$ exchange. SD refers to South Dakota samples. 


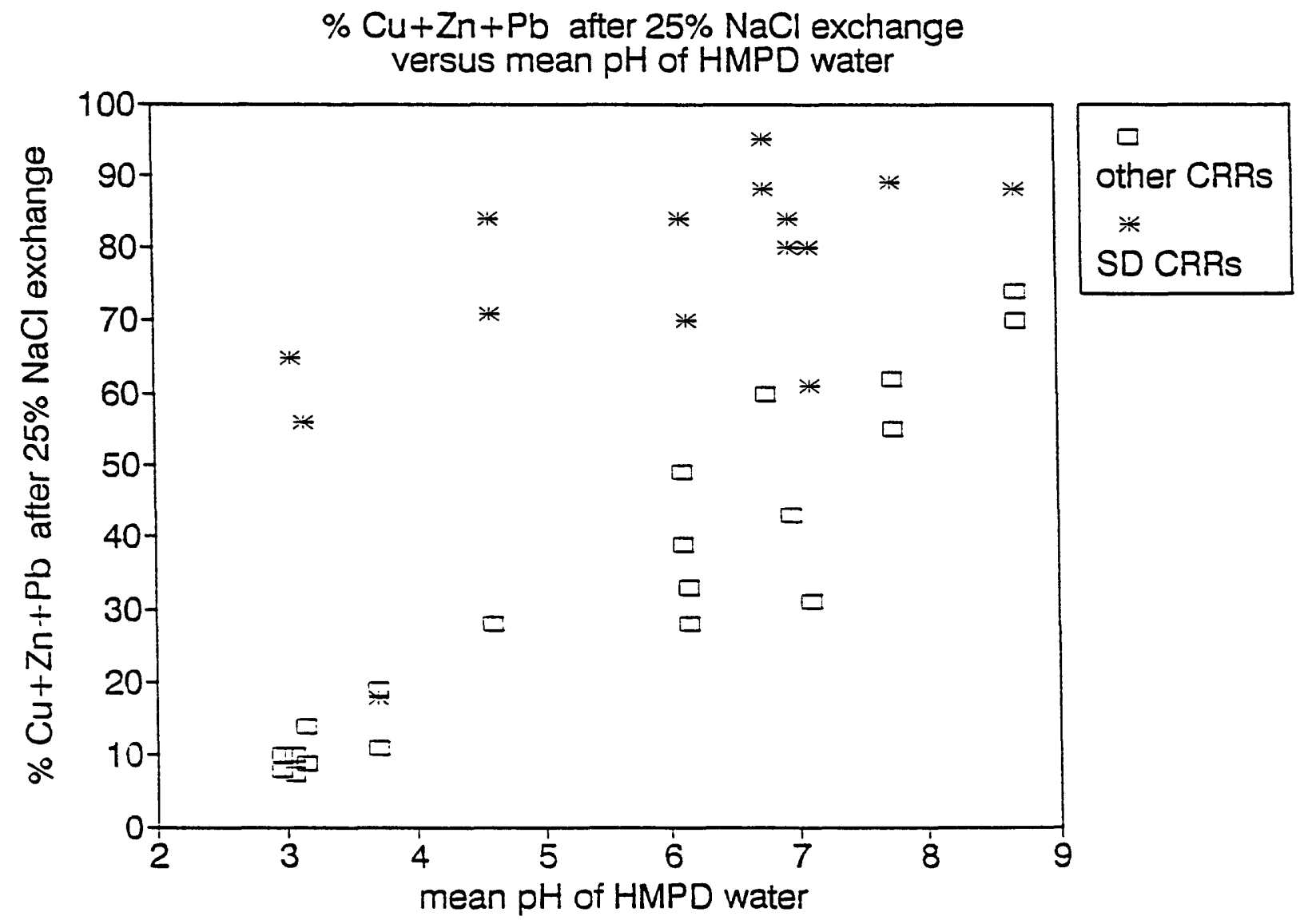

Figure 9.-Relations of the mean $\mathrm{pH}$ of the heavy-metal-polluted drainage (HMPD) of metal capture versus the amounts of copper + zinc + lead remaining in clinoptilolite-rich rocks (CRRs) after 25 weight percent $\mathrm{NaCl}$ exchange. SD refers to South Dakota samples. 
Mean pH of HMPD water vs. final $\mathrm{pH}$ of $\mathrm{NaCl}$ exchange solutions

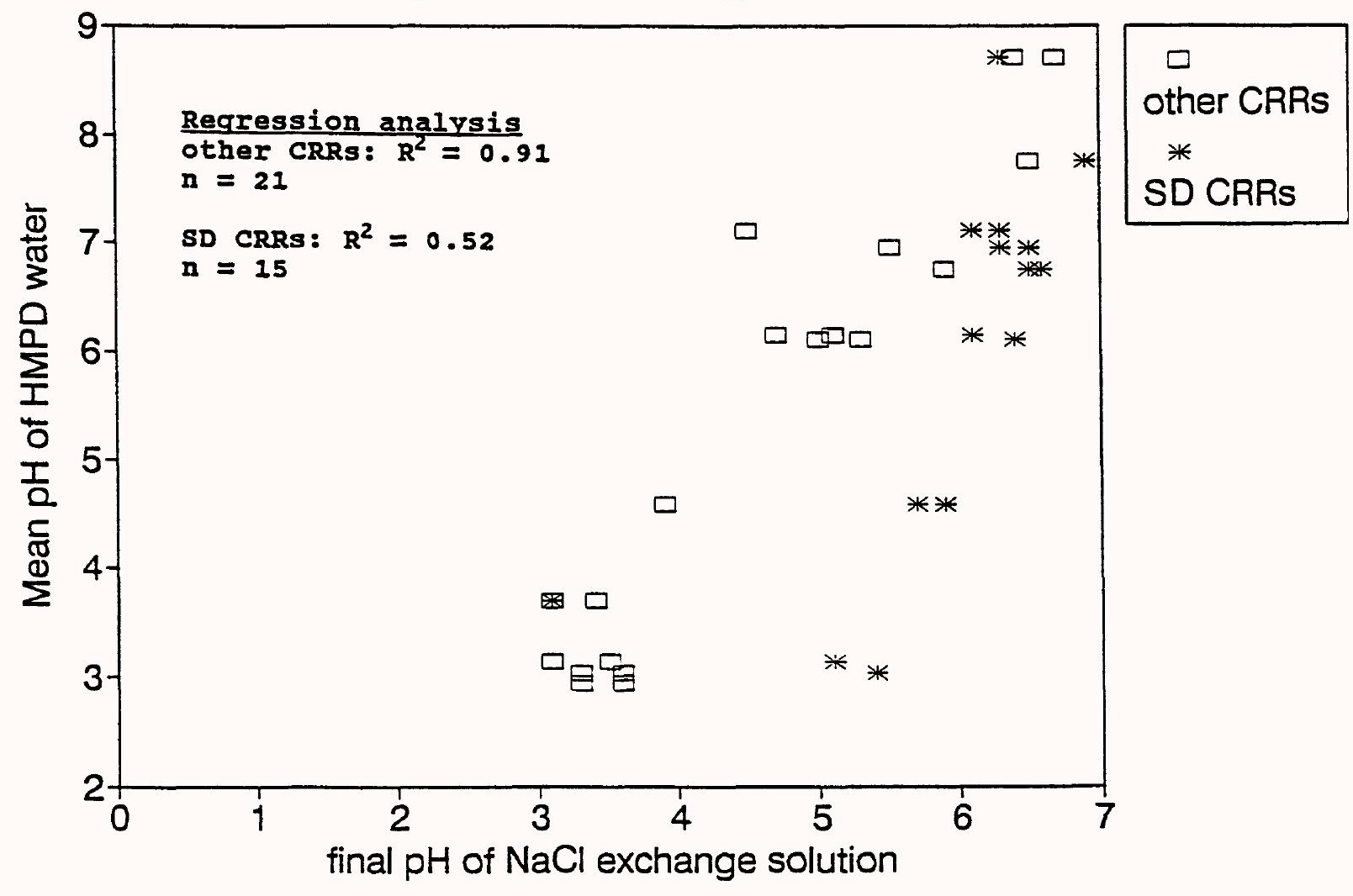

Figure 10.-Relations of the mean $\mathrm{pH}$ of HMPD water and the influence on the final $\mathrm{pH}$ of the 25 percent $\mathrm{NaCl}$ exchange solution. SD refers to South Dakota clinoptilolite-rich rocks (CRRs). $\mathrm{R}^{2}$, or variance, indicates how strongly the variables are correlated. $\mathrm{n}=$ number of observations. 
CRRs equilibrate with acidic solutions in less than 24 hours with water:rock ratios of $4: 1$ (Desborough, 1993); most of $\mathrm{H}^{+}$capture occurs in the first 30 minutes. For this study, the CRRs that captured heavy metals from HMPD waters were exposed to the 25 percent $\mathrm{NaCl}$ exchange solutions for 3 days in order to assure equilibration.

It is well known that, in general, the solubility of heavy metals such as $\mathrm{Cu}, \mathrm{Zn}$, and $\mathrm{Pb}$ increases as solution $\mathrm{pH}$ decreases. Conversely, these three metals become less soluble at higher $\mathrm{pH}$. It is chiefly for this reason that the $\mathrm{pH}$ of the 25 percent $\mathrm{NaCl}$ exchange solutions controls the amounts of $\mathrm{Cu}, \mathrm{Zn}$, and $\mathrm{Pb}$ released from most of the CRRs. This $\mathrm{pH}$ effect is evident in the first two data sets of table 5 where the acidified 10 percent $\mathrm{NaCl}$ exchange solutions $(\mathrm{pH}=2.6)$ caused removal of more $\mathrm{Zn}$ than the 18 percent $\mathrm{NaCl}$ solutions for all of the CRRs except SDA. Figure 11 is a plot of the $\mathrm{Zn}$ remaining in the $36 \mathrm{CRRs}$ versus the final $\mathrm{pH}$ of the $\mathrm{NaCl}$ exchange solutions. Regression analysis of these data gives an $R^{2}=0.87(n=36)$, indicating a strong positive correlation between these two variables. Figure 12 shows the same relations for $\mathrm{Pb}$ for $22 \mathrm{CRRs}$ that captured $\mathrm{Pb}$; regression analysis yields $\mathrm{R}^{2}=0.72(\mathrm{n}=22)$. Figure 13 illustrates the sum of $\mathrm{Cu}+\mathrm{Zn}+\mathrm{Pb}$ remaining in the $36 \mathrm{CRRs}$ versus the final $\mathrm{pH}$ of the exchange solutions and regression analysis yields $R^{2}=0.88(n=36)$, indicating a good correlation. The regression analyses for correlation, shown on figures 11,12 , and 13 , illustrate the influence of the final $\mathrm{pH}$ of the exchange solution on the amount of metal exchanged by the CRRs.

The mobility or exchangeability of heavy metals captured by CRRs appears to be a function of several factors: (1) the $\mathrm{pH}$ of the initial heavy-metal-bearing water, (2) the concentration of the exchange medium, (3) the CRR:exchange medium ratio, (4) $\mathrm{pH}$ of the exchange medium, and (5) the CRR used. The South Dakota samples (SD1, SDA, and SDC) are generally much more resistant to the extraction of $\mathrm{Cu}, \mathrm{Zn}$, and $\mathrm{Pb}$ than the other CRRs using the same exchange media; this seems to be related to their stronger preference for $\mathrm{H}^{+}$than the other CRRs. This stronger preference for $\mathrm{H}^{+}$results in a higher $\mathrm{pH}$ of the exchange solution, and thus a decreased exchangeability of $\mathrm{Cu}, \mathrm{Zn}$, and $\mathrm{Pb}$. For all of the CRRs tested in 145 exchange experiments, $\mathrm{Pb}$ is the most difficult to remove.

It may be important to recognize the significant differences in $\mathrm{Pb}$ retention for two of the most frequently tested CRRs-FLW and SDA. Each of these CRRs was field tested side-by-side and laboratory exchanged side-by-side in 17 tests (tables 2-9). Table 10 shows the mean and range for $\mathrm{Pb}$ captured from polluted drainage water and the mean and range of the amounts of $\mathrm{Pb}$ lost in these 17 exchanges for these two CRRs; only the ammonium sulfate and sodium chloride exchanges are shown. The mean amounts of $\mathrm{Pb}$ captured are similar for both CRRs. However, the mean amounts of $\mathrm{Pb}$ lost by FLW is six times greater than that lost by SDA.

Table 10.-Lead captured from polluted drainage water by FLW and SDA clinoptilolite-rich rocks (CRRs) and lead lost in 17 exchanges in ammonium sulfate and sodium chloride solutions

\begin{tabular}{|c|c|c|c|c|}
\hline \multirow{3}{*}{ CRR } & \multicolumn{2}{|c|}{$\mathrm{Pb}$ captured from drainage water } & \multicolumn{2}{|c|}{$\mathrm{Pb}$ lost in 17 exchanges } \\
\hline & mean & range & mean & range \\
\hline & \multicolumn{4}{|c|}{-parts per million-..-n-.... } \\
\hline FLW & 415 & $145-640$ & 65 & $0-300$ \\
\hline SDA & 425 & $130-810$ & 11 & $0-75$ \\
\hline
\end{tabular}




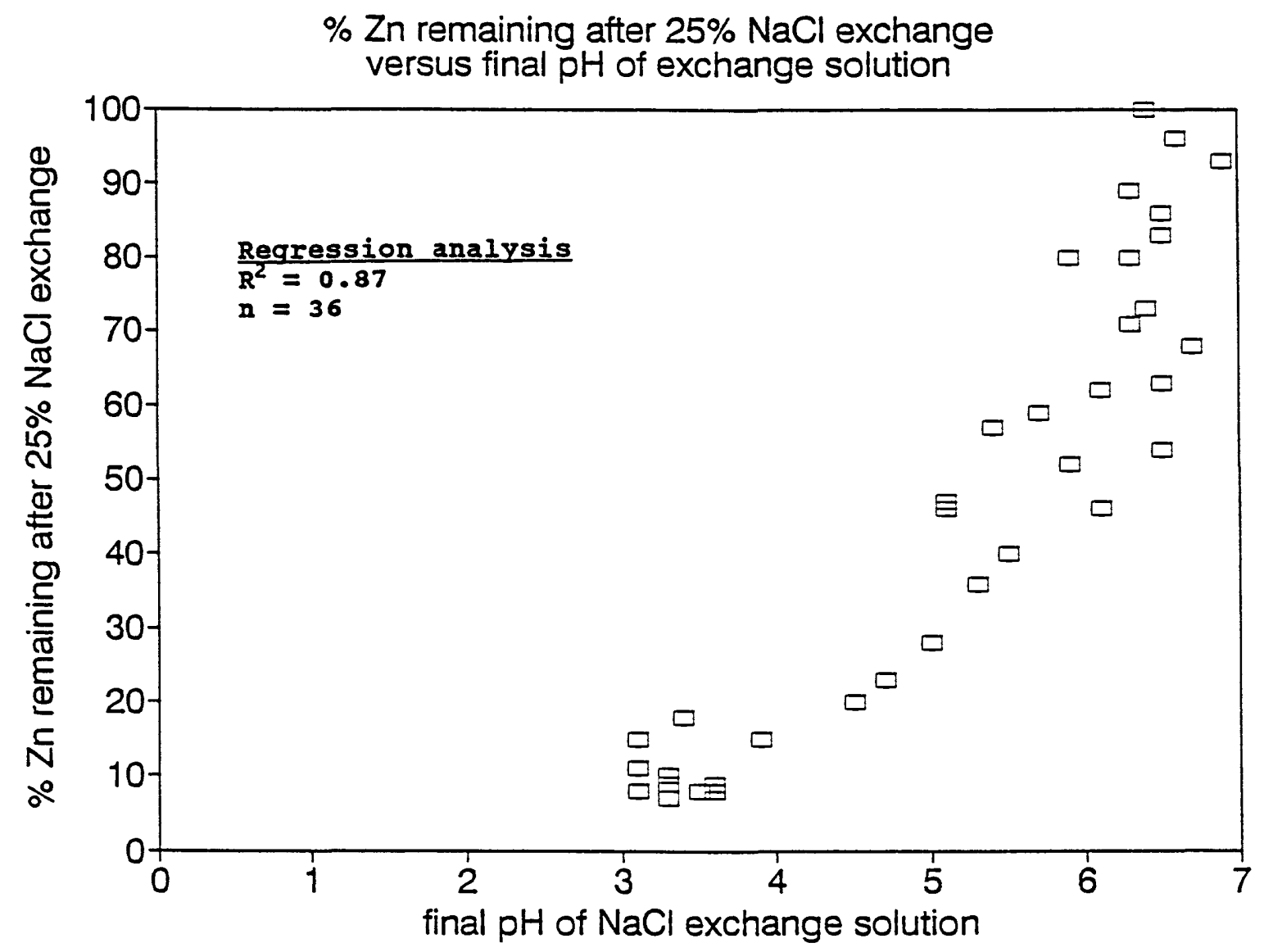

Figure 11.-Relations of the percent of $\mathrm{Zn}$ remaining in clinoptilolite-rich rocks (CRRs) after 25 percent $\mathrm{NaCl}$ exchange to the final $\mathrm{pH}$ of the 25 percent $\mathrm{NaCl}$ exchange solution. $\mathrm{R}^{2}$, or variance, indicates how strongly the variables are correlated. $\mathrm{n}=$ number of observations. 


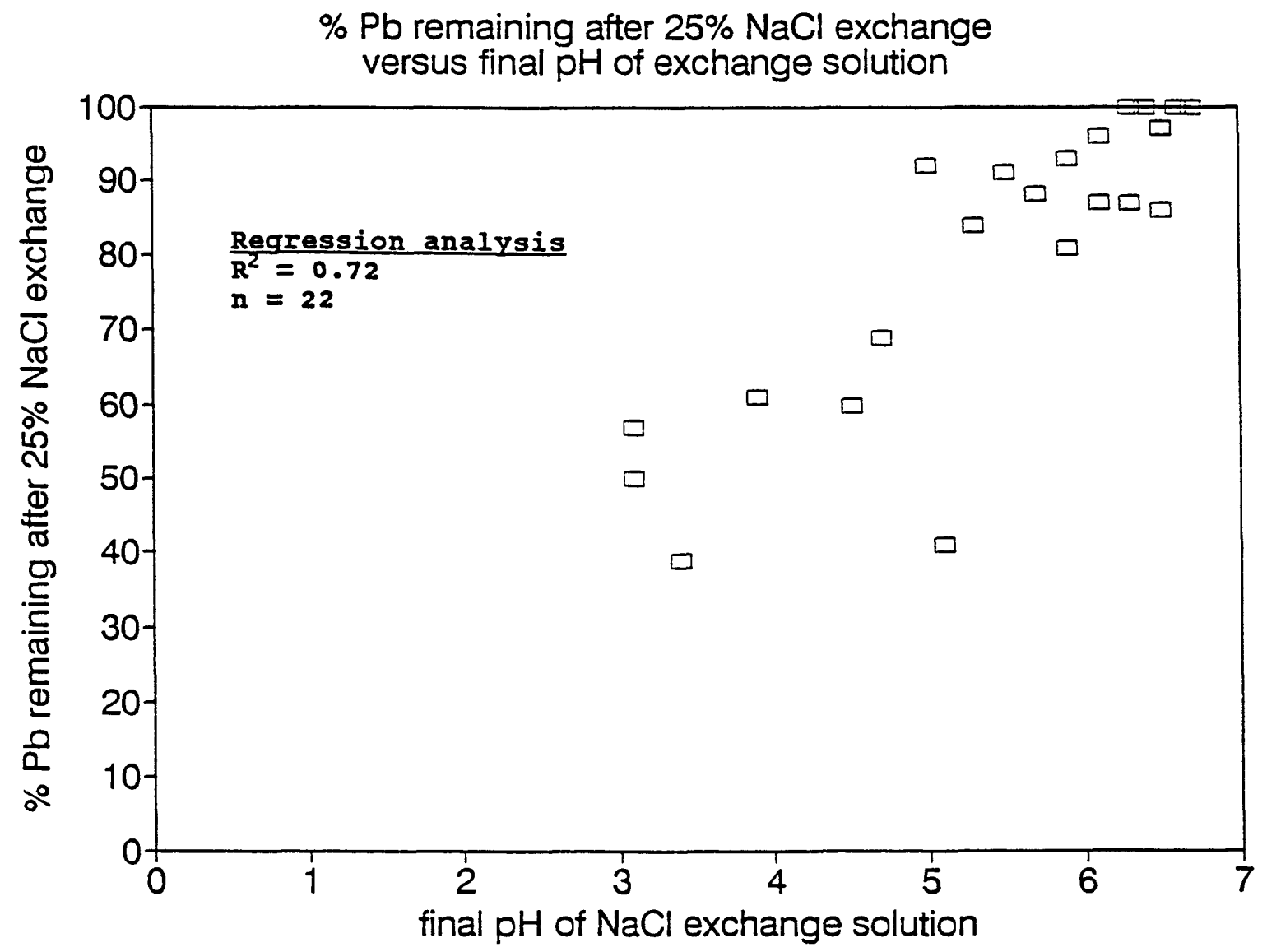

Figure 12.-Relations of the percent of $\mathrm{Pb}$ remaining in clinoptilolite-rich rocks (CRRs) after 25 percent $\mathrm{NaCl}$ exchange to the final $\mathrm{pH}$ of the 25 percent $\mathrm{NaCl}$ exchange solution. $\mathrm{R}^{2}$, or variance, indicates how strongly the variables are correlated. $\mathrm{n}=$ number of observations. 


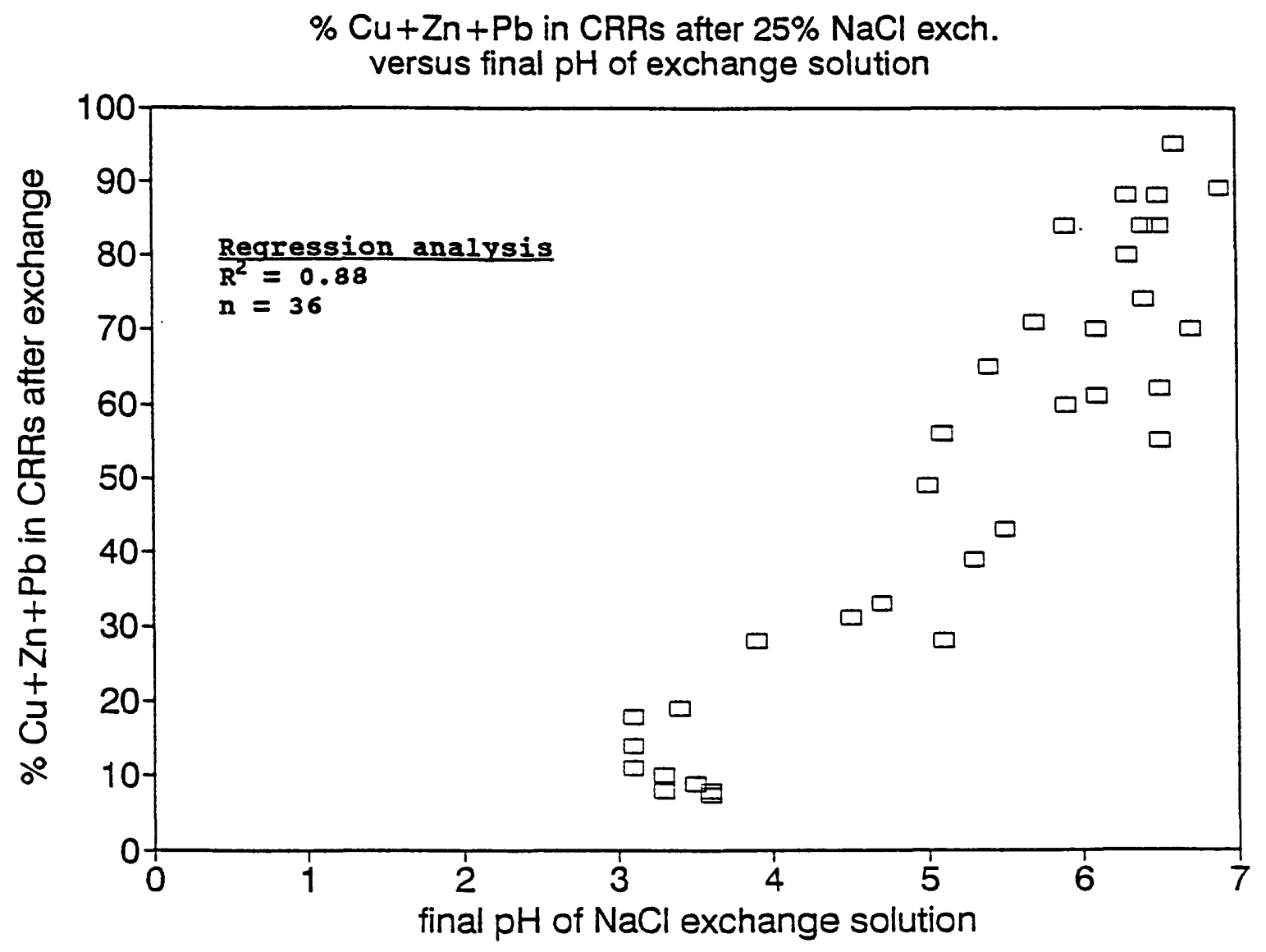

Figure 13.-Relations of the percent of $\mathrm{Cu}+\mathrm{Zn}+\mathrm{Pb}$ remaining in clinoptilolite-rich rocks (CRRs) after 25 percent $\mathrm{NaCl}$ exchange to the final $\mathrm{pH}$ of the 25 percent $\mathrm{NaCl}$ exchange solution. $\mathrm{R}^{2}$, or variance, indicates how strongly the variables are correlated. $\mathrm{n}=$ number of observations. 


\section{SUMMARY}

Only some of the raw CRRs tested in 1993 are quite efficient in capturing $\mathrm{Cu}, \mathrm{Zn}$, and $\mathrm{Pb}$ from HMPD water ranging in $\mathrm{pH}$ from about 3 to about 9 . Data given here concerning the mobility or cation-exchangeability of $\mathrm{Cu}, \mathrm{Zn}$, and $\mathrm{Pb}$ captured from HMPD water by raw CRRs may provide avenues to consider "semi-permanent" sequestration of these elements in some CRRs, or for the repeated capture and removal of these elements.

The FLW CRR is most efficient for capture of $\mathrm{Cu}$ and $\mathrm{Zn}$ in acidic (pH <5) HMPDs; both $\mathrm{Cu}$ and $\mathrm{Zn}$ can be easily removed from this $\mathrm{CRR}$ with $\mathrm{NaCl}$ exchange. It is not clear whether $\mathrm{Pb}$, which is not effectively removed by $\mathrm{NaCl}$ exchange, may eventually diminish the $\mathrm{Cu}$ and $\mathrm{Zn}$ loading capacity after several regenerations of FLW.

The South Dakota CRR has much greater heavy-metal-retention characteristics than the other CRRs, and thus it might be used passively to capture and then retain these heavy metals.

It appears that heavy metals captured by CRRs from waters with $\mathrm{pH}$ above about 5 could not be efficiently removed by $\mathrm{NaCl}$ exchange regeneration using near-neutral solutions. Acidified $\mathrm{NaCl}$ exchange solutions might be more effective for heavy-metal removal from some CRRs after exposure to HMPD water, but this possibility has not been thoroughly investigated.

\section{REFERENCES CITED}

Desborough, G.A., 1994, Efficacy of heavy-metal capture by clinoptilolite-rich rocks from heavy-metal-polluted water in five drainages in Colorado: U.S. Geological Survey OpenFile Report 94-140, 25 p. 1993, Ion-exchange of clinoptilolite-rich rocks in Argo drain water at Idaho Springs, Colorado, and related experimental aspects: U.S. Geological Survey Open-File Report 93-321, $23 \mathrm{p}$.

Schultz, L.E., and Zamzow, M.J., 1993, Acid mine drainage cleanup using natural zeolites, in Industrial Minerals in Environmental Applications Symposium: Geological Association of Canada, Cordilleran Section, Nov. 18-19, 1993, Vancouver, B.C., Program of Abstracts and Papers, p. 46-52.

U.S. Environmental Protection Agency, 1990, Toxicity characteristic leaching procedure (TCLP) (Method 1311), in Hazardous waste management system; Identification and listing of hazardous waste; Toxicity characteristics revisions; Final rule: Federal Register, March 29, 1990, Part II, Environmental Protection Agency, p. 11827-11877.

Vos, R.J., and O'Hearn, T.A., 1993, Use of zeolite to treat acid rock drainage from Brittannia minesite, in Industrial Minerals in Environmental Applications Symposium: Geological Association of Canada, Cordilleran Section, Nov. 18-19, 1993, Vancouver, B.C., Program of Abstracts and Papers, p. 53-61. 


\section{APPENDIX}

Concentrations of certain elements in clinoptilolite-rich rocks from 11 deposits in the Western U.S. and British Columbia, Canada. Chemical analysis by energy dispersive X-ray spectroscopy.

$$
\text { [n.a., not analyzed; n.r., not reported] }
$$

\begin{tabular}{|c|c|c|c|c|c|c|c|c|c|c|}
\hline \multirow{2}{*}{$\begin{array}{l}\text { Locality and } \\
\text { abbreviation }\end{array}$} & $\underline{\mathrm{Na}}$ & $\mathrm{K}$ & $\mathrm{Ca}$ & $\mathrm{Fe}$ & $\mathrm{Cu}$ & $\mathrm{Zn}$ & $\mathrm{Rb}$ & $\mathrm{Sr}$ & $\mathrm{Ba}$ & $\mathrm{Pb}$ \\
\hline & \multicolumn{4}{|c|}{ ppm $\times 10^{3}$} & \multicolumn{6}{|c|}{ - } \\
\hline \multicolumn{11}{|l|}{ British Columbia } \\
\hline Princeton-PBC & n.a. & 2.5 & 1.1 & 1.0 & 40 & 150 & 110 & 645 & 2,310 & $<40$ \\
\hline \multicolumn{11}{|l|}{ Colorado } \\
\hline Creede-CCO & n.a. & 3.2 & 1.7 & 0.9 & 20 & 80 & 190 & 485 & 590 & $<40$ \\
\hline \multicolumn{11}{|l|}{ Idaho } \\
\hline Crisman Hill-CHI & n.a. & 4.1 & 1.0 & 1.6 & 60 & 110 & 200 & 155 & 1,440 & $<40$ \\
\hline
\end{tabular}

Nevada

$\begin{array}{lllllllllll}\text { Fish Crk.-FCEN } & \text { n.a. } & 2.6 & 1.6 & 0.7 & 20 & 90 & 260 & 100 & 230 & <40 \\ \text { Fish Crk.-FCWN } & \text { n.a. } & 3.0 & 1.5 & 0.9 & 20 & 80 & 190 & 250 & 670 & <40\end{array}$

Oregon

Harney Lake-HLO Sheaville-SVO

$$
\begin{array}{llllllrrrr}
\text { n.a. } & 2.4 & 1.8 & 0.9 & 20 & 80 & 75 & 45 & 200 & <40 \\
\text { n.a. } & 4.1 & 1.0 & 1.8 & 20 & 90 & 160 & 190 & 1,190 & <40
\end{array}
$$

South Dakota

\begin{tabular}{|c|c|c|c|c|c|c|c|c|c|c|}
\hline Alamito Crk.-ACT & n.a. & 1.9 & 2.0 & 1.1 & 20 & 70 & 170 & 290 & 820 & $<40$ \\
\hline Tilden-TT & n.a. & 1.9 & 1.6 & 0.6 & 20 & 60 & 70 & 780 & 1,450 & $<40$ \\
\hline
\end{tabular}

$\begin{array}{lllllllllrl}\text { SD1 } & \text { n.a. } & 3.7 & 3.3 & 2.0 & 20 & 100 & 120 & 325 & 1,150 & <40 \\ \text { SDA } & 1.3 & 3.7 & 2.8 & 1.7 & 20 & 100 & 110 & 355 & 835 & <40 \\ \text { SDC } & \text { n.a. } & 3.7 & 1.9 & 2.0 & 20 & 60 & 120 & 355 & 1,020 & <40\end{array}$

$\underline{\text { Texas }}$

Wyoming

$\begin{array}{lllllllllll}\text { Ft.LaClede-FLW } & \text { n.a. } & 1.4 & 1.3 & 0.8 & 20 & 75 & 85 & 360 & 1,185<40 \\ \text { Corp reports } & 3.5 & 1.6 & 1.1 & 1.4 & - & - & & \end{array}$




\section{APPENDIX (continued)}

Dilutant minerals in clinoptilolite-rich rocks from 11 deposits in the Western U.S. and British Columbia, Canada. Determined by X-ray diffraction (Desborough, 1994).

[Minerals listed in order of decreasing abundance; "clay" refers to layer silicates with a 10-angstrom spacing; tr. = trace]

British Columbia

Princeton-PBC

Colorado

Creede-CCO

Idaho

Crisman Hill-CHI

Nevada

Fish Creek-FCEN

Fish Creek-FCWN

\section{Oregon}

Harney Lake-HLO

Sheaville-SVO

\section{South Dakota}

SD1

SDA

SDC

$\underline{\text { Texas }}$

Alamito Crk.-ACT

Tilden-TT

Wyoming

Ft. LaClede-FLW opal, potassium feldspar (K-feldspar), plagioclase

opal, K-feldspar, plagioclase, quartz, clay

opal, K-feldspar

K-feldspar, quartz, plagioclase

quartz, K-feldspar, plagioclase

$\mathrm{K}$-feldspar, plagioclase

tr. clay, opal(?)

plagioclase, calcite, quartz, opal, K-feldspar, clay quartz, calcite, plagioclase, K-feldspar, opal(?)

quartz, opal, calcite, K-feldspar, plagioclase, tr. clay

opal, plagioclase, clay

opal, quartz

plagioclase 